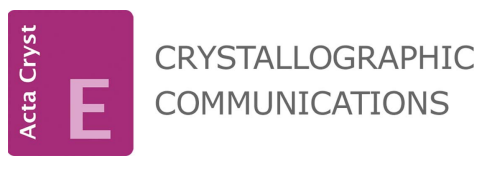

ISSN 2056-9890

Received 2 October 2019

Accepted 11 October 2019

Edited by A. J. Lough, University of Toronto, Canada

Keywords: crystal structure; Hirshfeld surface analysis; PIXEL calculations; epimeric mixture.

CCDC reference: 1944779

Supporting information: this article has supporting information at journals.iucr.org/e

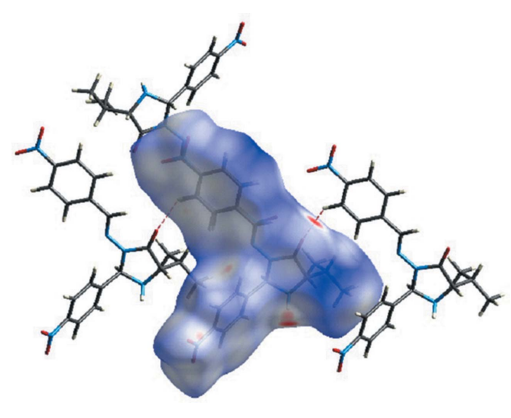

OPEN $\odot$ ACCESS

\section{Crystal structure, Hirshfeld surface analysis and PIXEL calculations of a 1:1 epimeric mixture of 3-[(4-nitrobenzylidene)amino]-2( $R, S)$-(4-nitro- phenyl)-5(S)-(propan-2-yl)imidazolidin-4-one}

\author{
Ligia R. Gomes, ${ }^{\text {a,b }}$ John Nicolson Low, ${ }^{\mathrm{c} *}$ James L. Wardell, ${ }^{\mathrm{c}, \mathrm{d}}$ Marcus V. N. de \\ Souza $^{d}$ and Cristiane F. da Costa ${ }^{d}$
}

${ }^{a}$ REQUIMTE, Departamento de Química e Bioquímica, Faculdade de Ciências da Universidade do Porto, Rua do Campo Alegre, 687, P-4169-007 Porto, Portugal, b ${ }^{\mathbf{b}}$ PP-ENAS-Faculdade de Ciências de Saúde, Escola Superior de Saúde da UFP, Universidade Fernando Pessoa, Rua Carlos da Maia, 296, P-4200-150 Porto, Portugal, 'Department of Chemistry, University of Aberdeen, Meston Walk, Old Aberdeen AB24 3UE, Scotland, and Instituto de Tecnologia em FármacosFarmanguinhos, Fundaçâo Oswaldo Cruz, 21041-250 Rio de Janeiro, RJ, Brazil. *Correspondence e-mail:

jnlow111@gmail.com

A 1:1 epimeric mixture of 3-[(4-nitrobenzylidene)amino]-2( $R, S)$-(4-nitrophenyl)$5(S)$-(propan-2-yl)imidazolidin-4-one, $\mathrm{C}_{19} \mathrm{H}_{19} \mathrm{~N}_{5} \mathrm{O}_{5}$, was isolated from a reaction mixture of 2(S)-amino-3-methyl-1-oxobutanehydrazine and 4-nitrobenzaldehyde in ethanol. The product was derived from an initial reaction of $2(S)$-amino3-methyl-1-oxobutanehydrazine at its hydrazine group to provide a 4-nitrobenzylidene derivative, followed by a cyclization reaction with another molecule of 4-nitrobenzaldehyde to form the chiral five-membered imidazolidin-4-one ring. The formation of the five-membered imidazolidin-4-one ring occurred with retention of the configuration at the 5-position, but with racemization at the 2-position. In the crystal, $\mathrm{N}-\mathrm{H} \cdots \mathrm{O}$ (nitro) hydrogen bonds, weak $\mathrm{C}-\mathrm{H} \cdots \mathrm{O}$ (carbonyl) and $\mathrm{C}-\mathrm{H} \cdots \mathrm{O}$ (nitro) hydrogen bonds, as well as $\mathrm{C}-\mathrm{H} \cdots \pi, \mathrm{N}-\mathrm{H} \cdots \pi$ and $\pi-\pi$ interactions, are present. These combine to generate a three-dimensional array. Hirshfeld surface analysis and PIXEL calculations are also reported.

\section{Chemical context}

Imidazolidin-4-ones have been widely studied (Blackmore \& Thompson, 2011) due to their wide range of uses, for example, as chiral ligands in catalysis (Lin et al., 2013; Mondini et al., 2013; Seebach et al., 2008; Puglisi et al., 2013) and for their biological activities (Elrod \& Worley, 1999; Gomes et al., 2004; Guerra et al., 2011; Barrow et al., 2007). As a consequence of their utility, there are a number of well-established synthetic routes, in particular those involving chiral synthesis (Blackmore \& Thompson, 2011; Eyilcim et al., 2018; Li et al., 2004; Vale et al., 2008, 2009; Catalano et al., 2011; Xu et al., 2010). As part of our studies on nitrogen-containing heterocyclic compounds, we report the crystal structure, Hirshfeld surface analysis and PIXEL calculations of a 1:1 epimeric mixture of 3-[(4-nitrobenzylidene)amino]-2( $R, S)$-(4-nitrophenyl)-5(S)(propan-2-yl)imidazolidin-4-one, 1.

\section{Structural commentary}

The title compound, $\mathbf{1}$, contains one molecule each of the epimers in the asymmetric unit. The 3-[(4-nitrobenzylidene)amino]-2(S)-(4-nitrophenyl)-5( $S$ )-(propan-2-yl)imidazolidin-4-one stereoisomer is termed MolA and the 3-[(4nitrobenzylidene)amino]-2(R)-(4-nitrophenyl)-5( $S)$-(propan-2- 
yl)imidazolidin-4-one stereoisomer is termed MolB (see Figs. $1 a$ and $1 b$ ). In MolA, the configurations at atoms C12 and C14 are $S$. In MolB, the configurations at atoms $\mathrm{C} 12$ and $\mathrm{C} 14$ are $R$ and $S$, respectively (Fig. 1). The asymmetric unit is shown in Fig. 1(c).

In both molecules, the imidazoline rings are puckered, the puckers in each case being a twist at $\mathrm{C} 12-\mathrm{N} 13$ and $\mathrm{C} 22-\mathrm{N} 23$ in MolA and MolB, respectively. In the case of MolA, the Cremer \& Pople puckering parameters (Cremer \& Pople, 1975) are $Q(2)$ of $0.287(2) \AA$ and $\varphi(2)$ of $54.7(5)^{\circ}$ for reference bond N11-C12; for MolB, $Q(2)$ is $0.103(3) \AA$ and $\varphi(2)$ is $230.3(15)^{\circ}$ for reference bond $\mathrm{N} 21-\mathrm{C} 22$. In MolA, the dihedral angles between the mean planes of the imidazoline ring and the benzene ring (pivot atom C121) is $45.83(18)^{\circ}$, between the imidazoline ring and the benzene ring (pivot atom $\mathrm{C131}$ ) is $28.04(12)^{\circ}$ and between the two benzene rings is $69.86(11)^{\circ}$. In MolB, the dihedral angles between the mean planes of the imidazoline ring and the benzene ring (pivot atom C221) is $59.83(13)^{\circ}$, between the imidazoline ring and the benzene ring (pivot atom C131) is $6.86(13)^{\circ}$ and between the two benzene rings is 66.38 (11).

\section{Supramolecular features}

\subsection{Intermolecular interactions and contacts}

As seen, each of the molecules of the asymmetric unit (Fig. 1c) has two nitro groups, whose $\mathrm{O}$ atoms can act as acceptors for hydrogen bonding, and three rings that are able to participate in $\pi-\pi$ stacking. Fig. $1(c)$ shows the two molecules labelled for the nitro $\mathrm{O}$ atom and the oxo atoms (O15 and $\mathrm{O} 25$ ), as well as the identification of ring $A$ (benzene rings with pivot atoms $\mathrm{C} 131$ and $\mathrm{C} 231$ ), $B$ (benzene rings with pivot atoms $\mathrm{C} 121$ and $\mathrm{C} 221$ ) and $C$ (imidazoline rings).

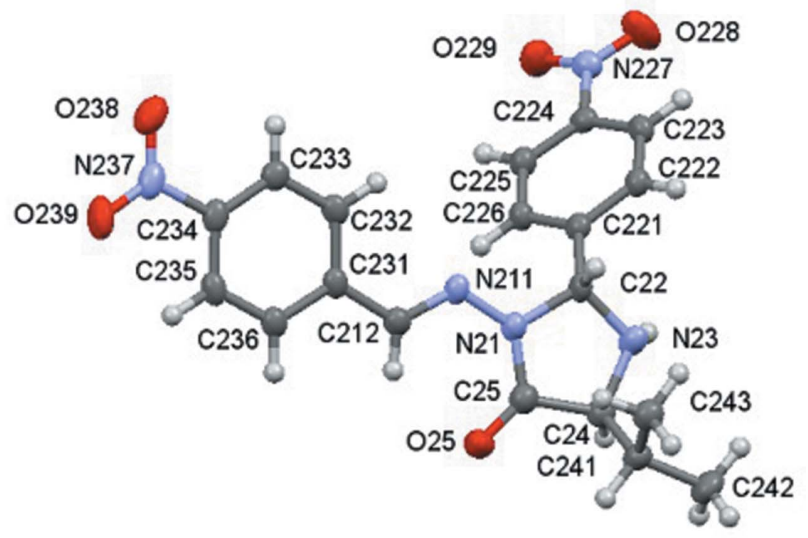

1b
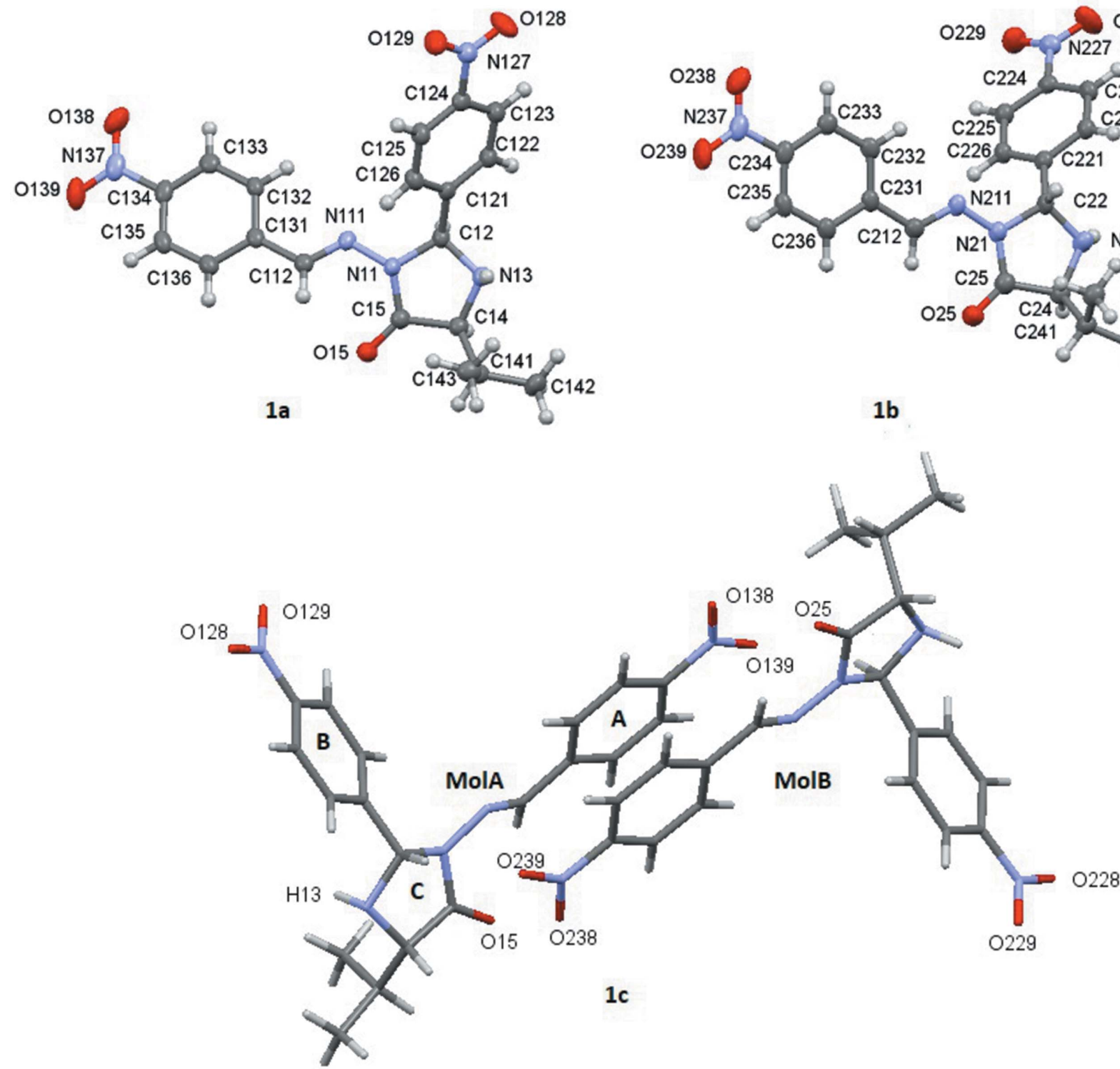

Figure 1

Compound 1, showing the molecular structures and numbering schemes for $(a)$ MolA and $(b)$ MolB. Displacement ellipsoids are drawn at the $50 \%$ probability level. (c) The asymmetric unit containing MolA and MolB, with rings designated as $A, B$ and $C$. 


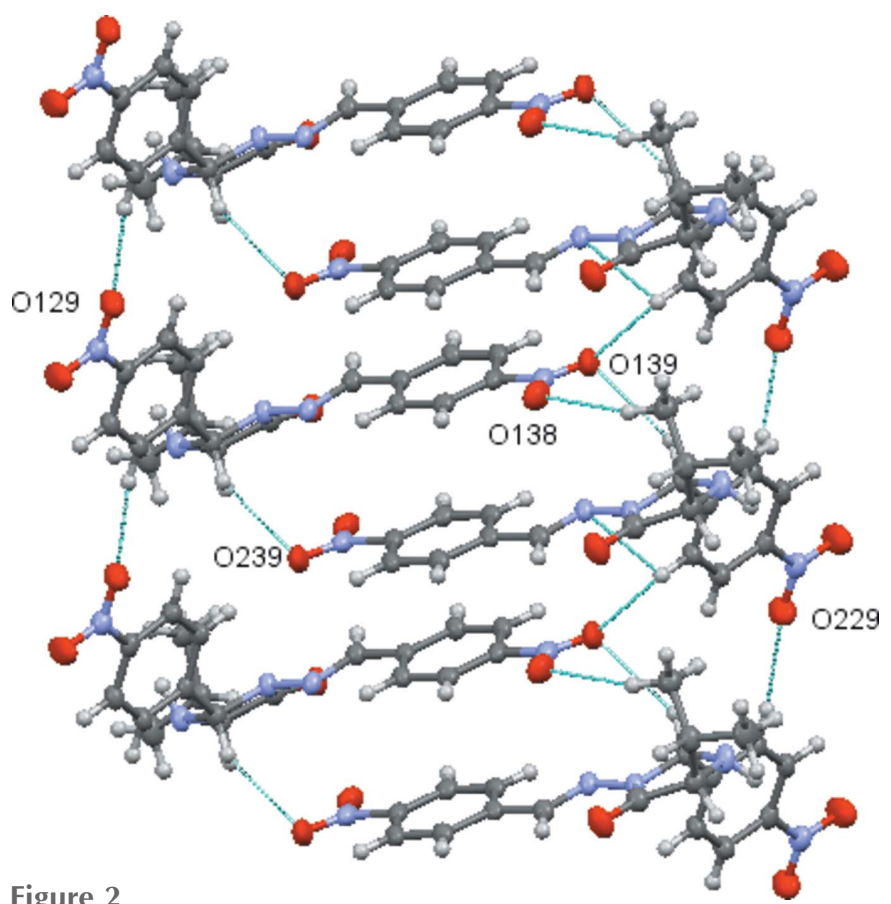

Dimers of $\pi-\pi$ stacked MolA and MolB, which comprise the asymmetric unit, further linked by $\pi-\pi$ interactions extending the chain by unit translation along the $a$ axis. The $\pi-\pi$ interactions are augmented by $\mathrm{C}-$ $\mathrm{H}$... O hydrogen bonds.

A PLATON analysis (Spek, 2009) indicates the possibility in 1 of $\mathrm{N}-\mathrm{H} \cdots \mathrm{O}$ (nitro), $\mathrm{C}-\mathrm{H} \cdots \mathrm{O}$ (nitro) and $\mathrm{C}-$ $\mathrm{H} \cdots \mathrm{O}(\mathrm{oxo})$ hydrogen bonds, and $\mathrm{C}-\mathrm{H} \cdots \pi, \mathrm{N}-\mathrm{O} \cdots \pi$ and $\pi-\pi$ intermolecular interactions. All details of the hydrogen bonding (molecular contacts) and $\pi-\pi$ stacking are given in Tables 1 and 2, respectively. Noticeable among these is the three-centred hydrogen bond between N23 in MolB and the nitro-group atoms O128/O129 in MolA (symmetry code: $x+1$, $y-1, z+1)$, which generate chains running parallel to the [1111] direction. Within the chosen asymmetric unit (see Fig. 1c), the benzene rings with pivot atoms C131 and C231 are $\pi-\pi$ stacked, forming a dimer. This stacking is supplemented by the $\mathrm{C} 22-\mathrm{H} 22 \cdots \mathrm{O} 139, \mathrm{C} 243-\mathrm{H} 24 D \cdots \mathrm{O} 138$ and $\mathrm{C} 12-$
Table 1

Hydrogen-bond geometry $\left(\AA{ }^{\circ}\right)$.

\begin{tabular}{lllll}
\hline$D-\mathrm{H} \cdots A$ & $D-\mathrm{H}$ & $\mathrm{H} \cdots A$ & $D \cdots A$ & $D-\mathrm{H} \cdots A$ \\
\hline $\mathrm{N} 23-\mathrm{H} 23 \cdots \mathrm{O} 128^{\mathrm{i}}$ & $0.89(4)$ & $2.55(4)$ & $3.338(3)$ & $147(3)$ \\
$\mathrm{N} 23-\mathrm{H} 23 \cdots \mathrm{O} 129^{\mathrm{i}}$ & $0.89(4)$ & $2.36(4)$ & $3.202(3)$ & $159(3)$ \\
$\mathrm{C} 112-\mathrm{H} 112 \cdots \mathrm{O} 15$ & 0.95 & 2.30 & $2.822(3)$ & 114 \\
$\mathrm{C} 212-\mathrm{H} 212 \cdots \mathrm{O} 25$ & 0.95 & 2.16 & $2.832(3)$ & 127 \\
$\mathrm{C} 133-\mathrm{H} 133 \cdots \mathrm{O} 15^{\mathrm{ii}}$ & 0.95 & 2.29 & $3.154(3)$ & 151 \\
$\mathrm{C} 233-\mathrm{H} 233 \cdots \mathrm{O} 25^{\mathrm{iii}}$ & 0.95 & 2.36 & $3.141(3)$ & 139 \\
$\mathrm{C} 243-\mathrm{H} 24 D \cdots \mathrm{O} 138$ & 0.98 & 2.52 & $3.480(3)$ & 165 \\
$\mathrm{C} 122-\mathrm{H} 122 \cdots \mathrm{O} 129^{\text {iv }}$ & 0.95 & 2.48 & $3.212(3)$ & 134 \\
$\mathrm{C} 222-\mathrm{H} 222 \cdots \mathrm{O} 229^{\mathrm{v}}$ & 0.95 & 2.60 & $3.297(3)$ & 131 \\
$\mathrm{C} 226-\mathrm{H} 226 \cdots \mathrm{O} 139^{\text {iv }}$ & 0.95 & 2.57 & $3.197(3)$ & 124
\end{tabular}

Symmetry codes: (i) $x+1, y-1, z+1$; (ii) $x, y-1, z$; (iii) $x, y+1, z$; (iv) $x+1, y, z$; (v) $x-1, y, z$.

H12 ․ O239 weak hydrogen bonds. Details are given in Tables 1 and 2 . Such $\pi-\pi$-linked dimers are linked by further $\pi-\pi$ interactions, forming a $\pi-\pi$ stacked column, which extends along the $a$ axis by unit translation (see Table 2). The C122$\mathrm{H} 122 \ldots \mathrm{O} 129$ and $\mathrm{C} 224-\mathrm{H} 224 \cdots \mathrm{O} 229$ weak hydrogen bonds

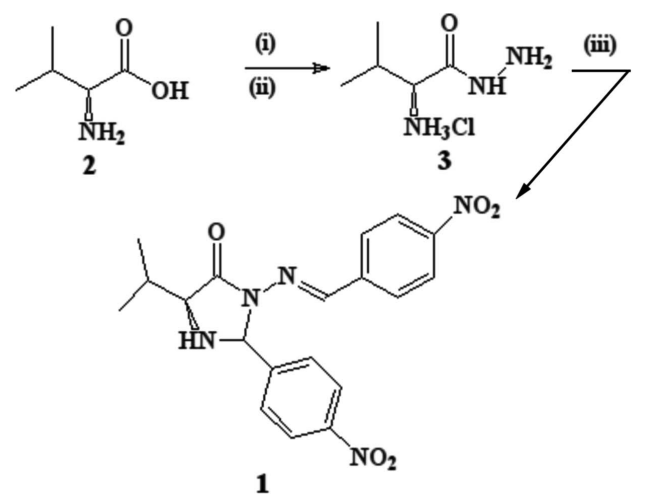

Scheme 1; Reagents and Conditions: (i) $\mathrm{SOCh}_{2}, \mathrm{MeOH}$; (ii) $\mathrm{NH}_{2} \mathrm{NH}_{2}$. EtOH, (iii) 4-NO2 $\mathrm{PhCHO}$, EtOH, reflux

supplement the interdimer $\pi-\pi$ stacking (Fig. 2). These $\pi-\pi$ stacked dimers are also linked by the N23-H23 ‥O128/O129 hydrogen bond described above; this interaction creates chains, which propagate parallel to the [11ㅣ] direction (Fig. 3,

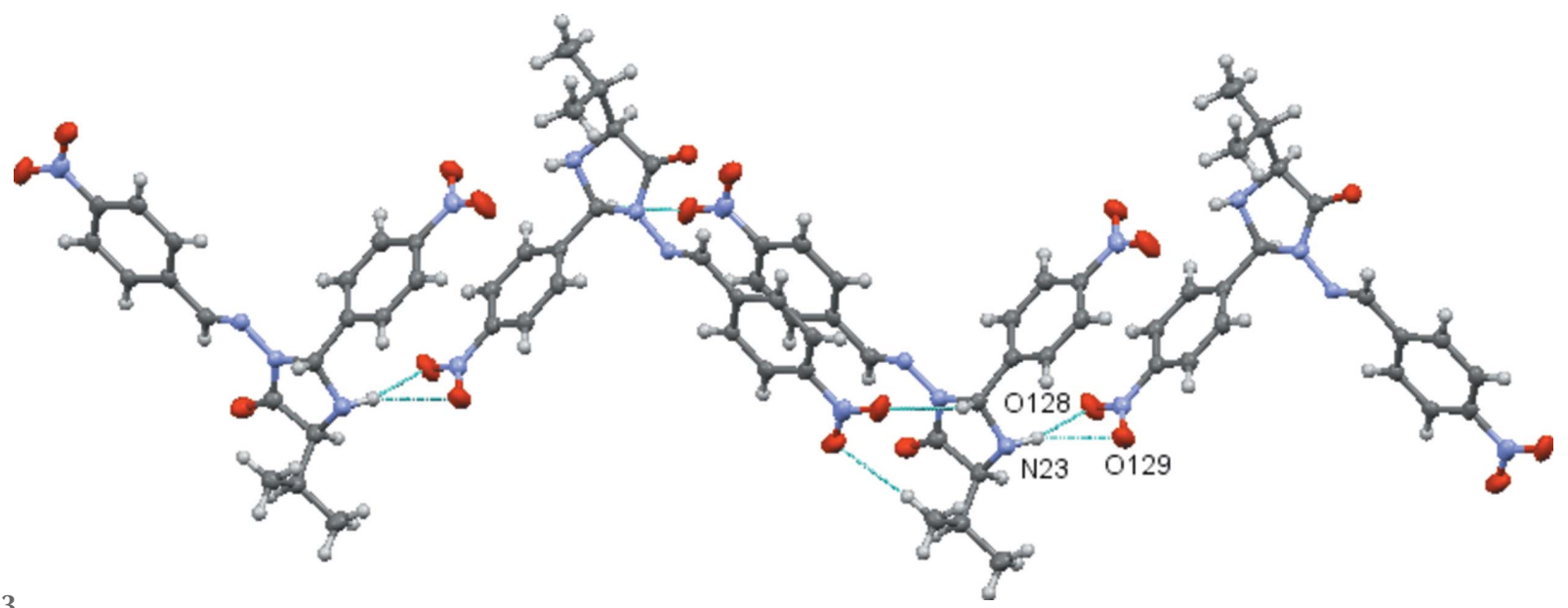

Figure 3

Part of a chain of molecules linked by N23 ...O128/129 hydrogen bonds connect the asymmetric unit dimers into a chain. Only the atoms in the $\mathrm{N} 23$. . O128/O129 three-centred hydrogen bond are labelled for clarity. 
Table 2

Analysis of short ring interactions with the $C g-C g$ distances.

\begin{tabular}{llll}
\hline$C g(I)$ & $C g(J)$ & $C g-C g$ & Slippage \\
\hline$C g 3$ & $C g 6(x-1, y, z)$ & $3.6278(13)$ & 1.394 \\
$C g 3$ & $C g 6(x, y, z)$ & $3.7548(13)$ & 1.772 \\
$C g 6$ & $C g 3(x+1, y, z)$ & $3.6277(13)$ & 1.433 \\
$C g 6$ & $C g 3(x, y, z)$ & $3.7548(13)$ & 1.672 \\
\hline
\end{tabular}

Notes: $C g(I)=$ plane number $I, C g-C g=$ distance between ring centroids $(\AA)$, slippage = distance between $C g(I)$ and perpendicular projection of $C g(J)$ on ring $I(\AA)$. $C g 3$ and $C g 6$ are the centroids of the rings with pivot atoms $\mathrm{C} 131$ and $\mathrm{C} 231$, respectively.

see Table 1 for details). The $\mathrm{C} 112-\mathrm{H} 112 \ldots \mathrm{O} 15$ and $\mathrm{C} 212-$ $\mathrm{H} 21 \cdots \mathrm{O} 25$ are possible intramolecular hydrogen bonds. The $\mathrm{C} 133-\mathrm{H} 133 \cdots \mathrm{O} 15(x, y-1, z)$ and $\mathrm{C} 233-\mathrm{H} 233 \cdots \mathrm{O} 25(x$, $y-1, z)$ hydrogen bonds, found by PLATON, separately create $C(9)$ chains that propagate in the direction of the $b$ axis. There is one intermolecular $\mathrm{C}-\mathrm{H} \cdots \pi$ interaction involving $\mathrm{C} 143-\mathrm{H} 14 A \cdots C g 2(x, y+1, z)[C g 2$ is the centroid of the benzene ring with pivot atom $\operatorname{C121}(x, y+1, z)]$, with an
$\mathrm{H} \cdots \mathrm{Cg} 2$ distance of $2.95^{\circ}$, an angle at $\mathrm{H}$ of $128^{\circ}$ and a $\mathrm{C} 143 \cdots \mathrm{Cg} 2$ distance of $3.638(3)^{\circ}$.

\subsection{Hirshfeld surface and quantitative analyses of inter- molecular interactions}

Hirshfeld surfaces (Spackman \& Jayatilaka, 2009) and twodimensional fingerprint (FP) plots (Spackman \& McKinnon, 2002) provide complementary information concerning the intermolecular interactions deduced from the PLATON analysis. The Hirshfeld analysis, generated using CrystalExplorer (Version 3.1; Wolff et al., 2012) and mapped over $d_{\text {norm }}$ (ranging from -0.329 to 1.708 ), indicated red areas related to specific intermolecular short contacts (see Figs. 4-7).

Briefly, the Hirshfeld surface analysis revealed that in MolA all the $\mathrm{O}$ atoms participate in hydrogen bonding, but in MolB only three do, the exception being $\mathrm{O} 238$ in ring $A$. A summary of these interactions is made in Table 3. Carbonyl atoms $\mathrm{O} 15$ or $\mathrm{O} 25$ of heterocyclic ring $C$ and nitro atoms $\mathrm{O} 129$ or O229 of ring
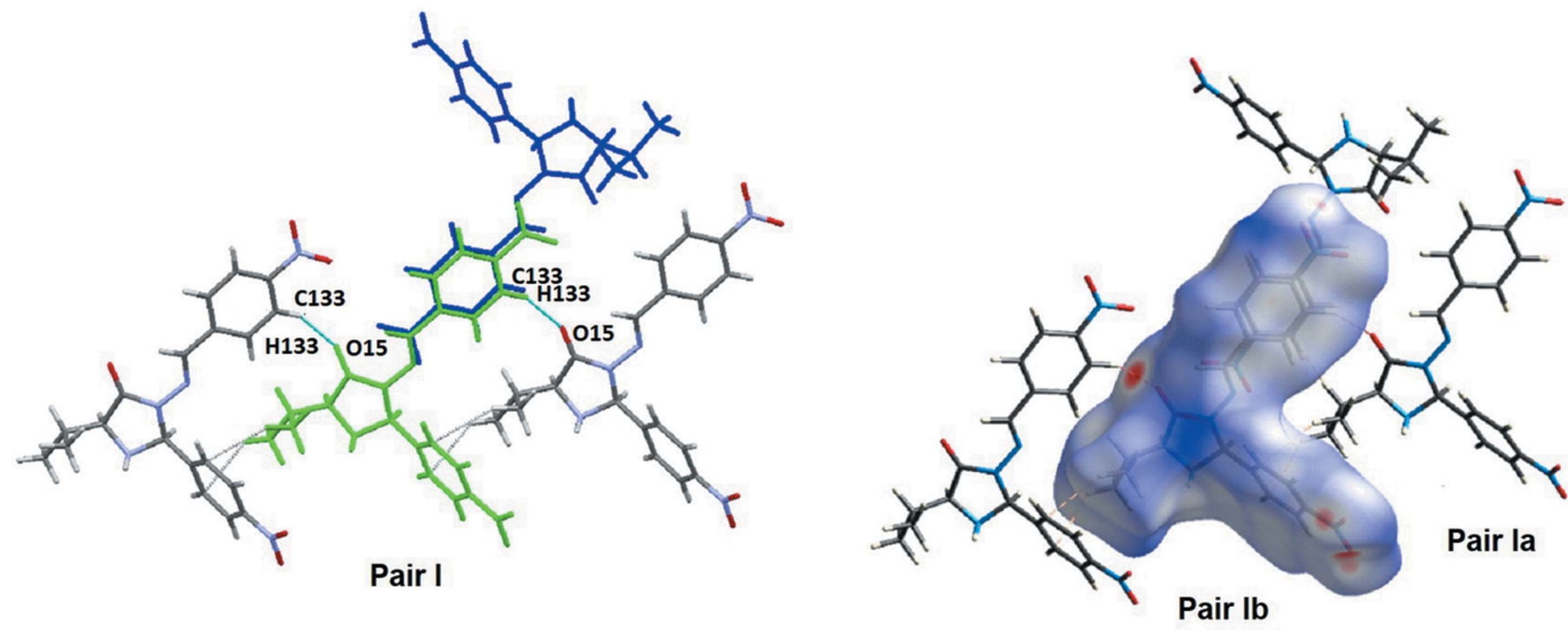

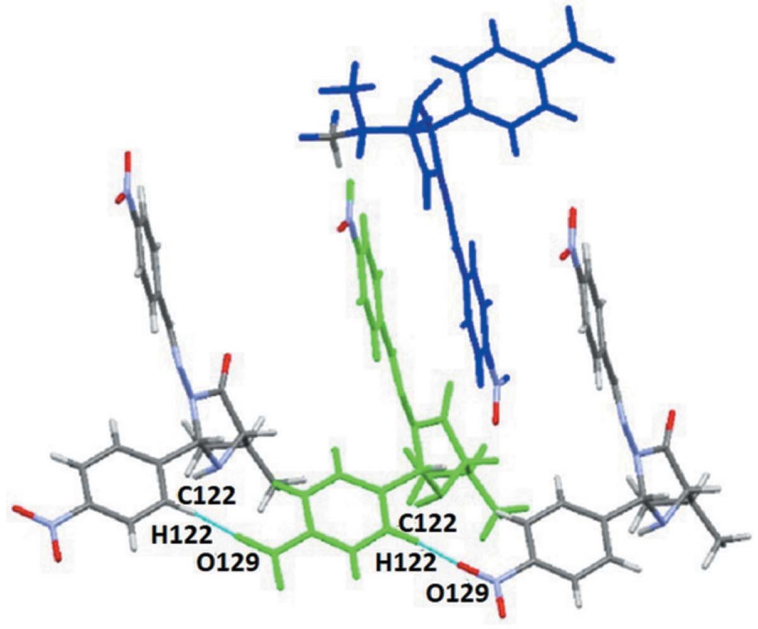

Pair II

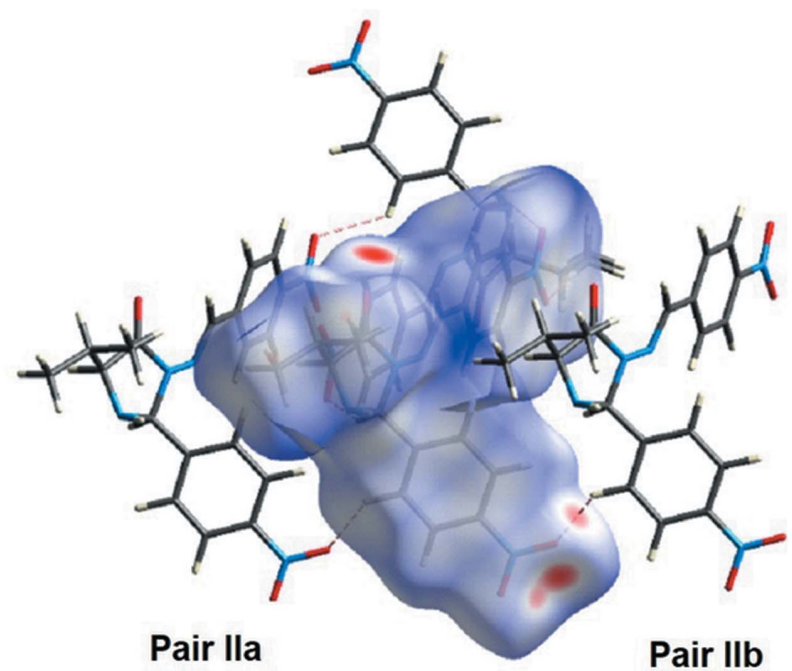

Figure 4

Interactions connecting molecule pairs I and II, and a view of the Hirsfeld surface. 
Table 3

Summary of the hydrogen bonding.

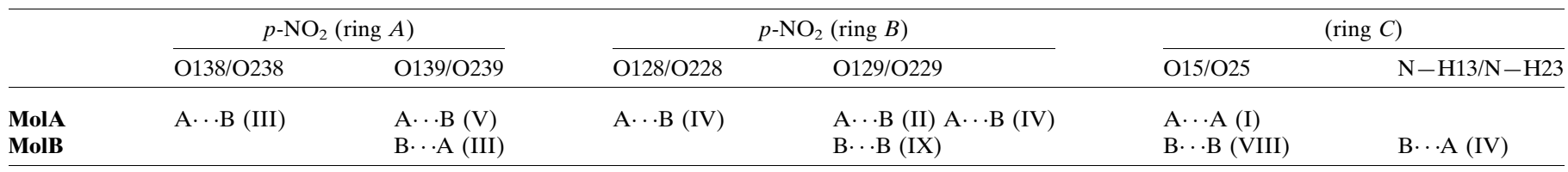

$B$ are involved in hydrogen bonding between two similar molecules, i.e. MolA $\cdots$ MolA or MolB $\cdots$ MolB. Those pairs interact in a similar way. All the nitro-group O atoms of MolA (O128, O129, O138 and O139) act as acceptors for $\mathrm{H}$ atoms of MolB.

PIXEL energy calculations, as implemented in PIXEL3.1 (Gavezzotti, 2003, 2008), were run in order to calculate the total stabilization energy of the crystal packing, $E_{\text {tot }}$, distrib- uted as Coulombic, $E_{\text {Coul }}$, polarization, $E_{\mathrm{pol}}$, dispersion, $E_{\mathrm{disp}}$, and repulsion, $E_{\text {rep }}$, terms. Partial analysis of the PIXEL calculations have been made and the results obtained were used to identify pairs of molecules within the crystal network that most contribute to the total energy of the packing.

The compound crystallized with two molecules (MolA and MolB) in the asymmetric unit and each has five $\mathrm{O}$ atoms that

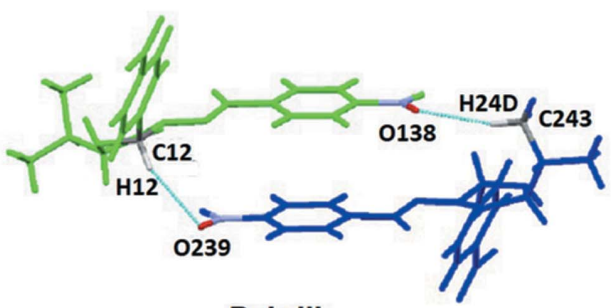

Pair III

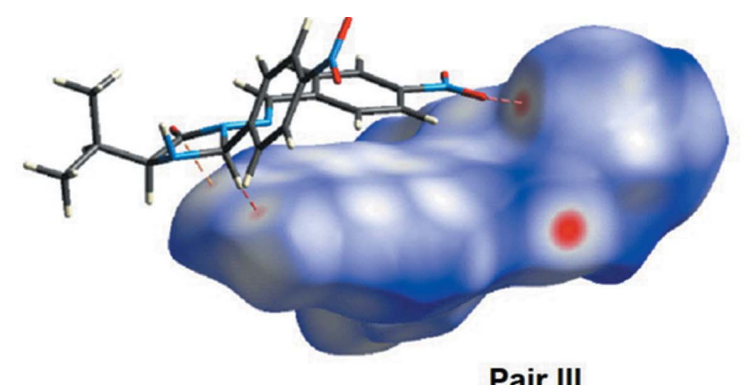

Pair III
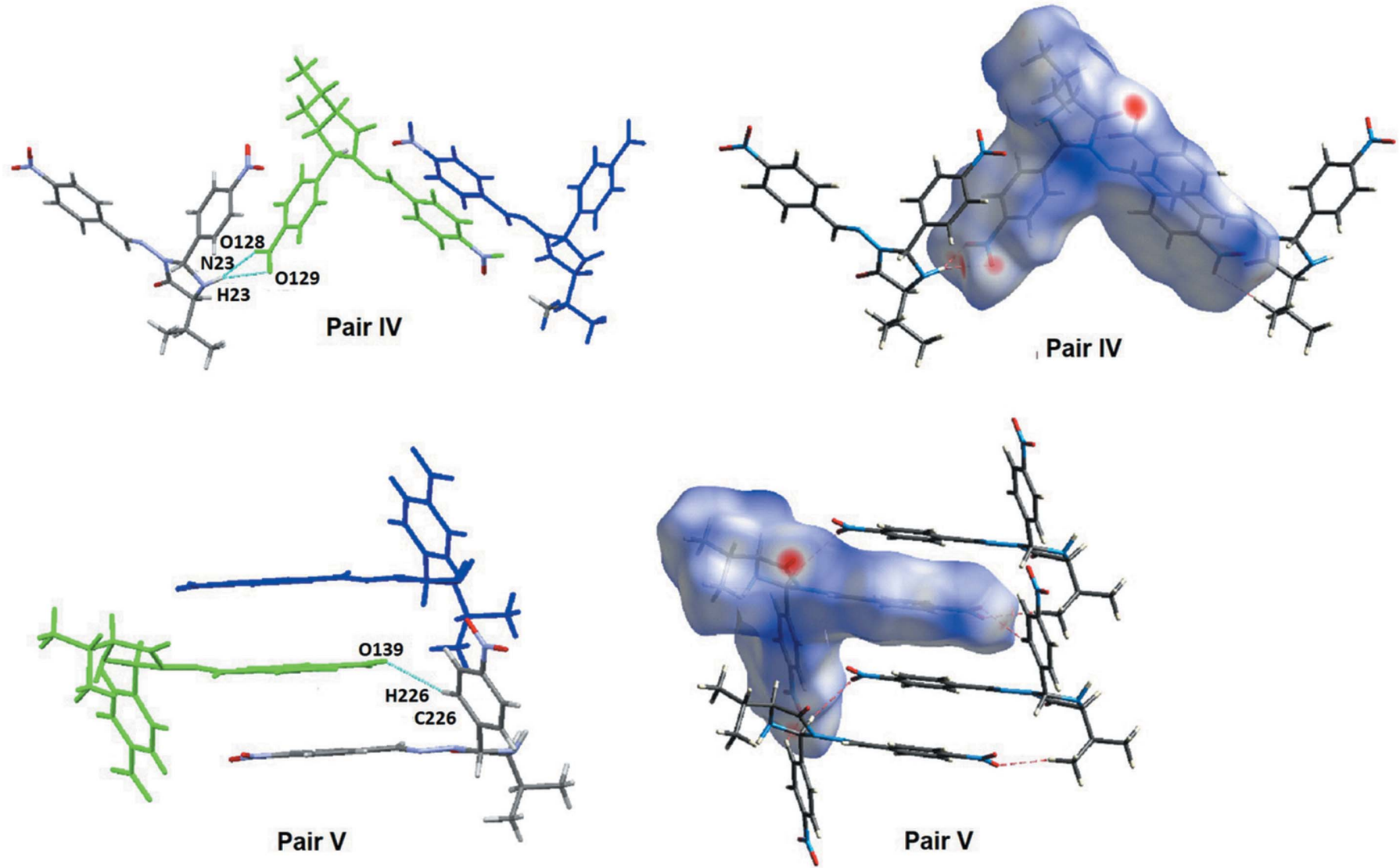

Figure 5

Top: interactions connecting molecule pair III and a view of the Hirshfeld surface. Middle: interactions connecting molecule pair IV and a view of the Hirshfeld surface. Bottom: interactions connecting molecule pair V and a view of the Hirshfeld surface. 
Table 4

Percentages for atom-atom close contacts.

\begin{tabular}{|c|c|c|c|c|c|c|c|c|c|c|}
\hline 1 & $\mathrm{H} \cdots \mathrm{H}$ & $\mathrm{H} \cdots \mathrm{O} / \mathrm{O} \cdots \mathrm{H}$ & $\mathrm{H} \cdots \mathrm{C} / \mathrm{C} \cdots \mathrm{H}$ & $C \cdots C$ & $\mathrm{H} \cdots \mathrm{N} / \mathrm{N} \cdots \mathrm{H}$ & $\mathrm{O} \cdots \mathrm{C} / \mathrm{C} \cdots \mathrm{O}$ & $\mathrm{O} \cdots \mathrm{N} / \mathrm{N} \cdots \mathrm{O}$ & $\mathrm{C} \cdots \mathrm{N} / \mathrm{N} \cdots \mathrm{C}$ & $\mathrm{N} \cdots \mathrm{N}$ & $\mathrm{O} \cdots \mathrm{O}$ \\
\hline MolA & 36.9 & 35.5 & 11.3 & 4.7 & 2.2 & 3.1 & 1.7 & 1.9 & 1.0 & 1.6 \\
\hline MolB & 36.5 & 36.2 & 11.5 & 4.7 & 1.6 & 3.3 & 1.7 & 1.9 & 1.0 & 1.6 \\
\hline
\end{tabular}

may be involved in the formation of hydrogen bonds, which are labelled in Fig. 1(c). In short, each molecule has two 4$\mathrm{NO}_{2}$-phenyl substituents, one substituent connected to the imine C atom, ring $A$ (pivot atoms C131 and C231 in MolA and MolB, respectively), and the other to the imidazoline ring, ring $C$ (pivot atoms $\mathrm{C} 121$ and $\mathrm{C} 221$ in MolA and MolB, respectively). In addition, there is a carbonyl $\mathrm{O}$ atom in heterocyclic ring $C$ (pivot atoms N11 and N21 in MolA and MolB, respectively), together with a potential donor, i.e. the $-\mathrm{NH}$ group on the same ring.

The Hirshfeld surface mapped over $d_{\text {norm }}$ ranging from -0.329 to 1.708 for $\mathbf{1}$ show various red areas due to intramolecular short contacts (refer to Figs. 4-7). Briefly, the analysis revealed that in $\mathbf{M o l A}$ all the $\mathrm{O}$ atoms participate in hydrogen bonds, while only one of the nitro $\mathrm{O}$ atoms of $\operatorname{ring} A$ of MolB establishes interactions. A summary of these interactions is made in Table 3. The carbonyl $\mathrm{O}$ atom of heterocyclic ring $C$ and the nitro atoms $\mathrm{O} 129$ or $\mathrm{O} 229$ of ring $B$ are involved in hydrogen bonding between two molecules with the same labels, that is A $\cdots$ A or B $\cdots \mathrm{B}$. These pairs interact in a similar way. In contrast, it seems that all the $\mathrm{O}$ atoms of MolA act as acceptors for $\mathrm{H}$ atoms of MolB. Some $\mathrm{C} \cdot \boldsymbol{\pi}$ interactions that define some substructures are identified in Table 3.

PIXEL energy calculations, as implemented in PIXEL3.1 (Gavezzotti, 2003, 2008), give a total stabilization energy of $-170.4 \mathrm{~kJ} \mathrm{~mol}^{-1}$ for the crystal packing, distributed as follows: $E_{\text {Coul }}=-78.4, E_{\text {pol }}=-30.6, E_{\text {disp }}=-199.51$ and $E_{\text {rep }}=$ $138.2 \mathrm{~kJ} \mathrm{~mol}^{-1}$ for Coulombic, polarization, dispersion and repulsion energies, respectively. The polarization term is clearly less important than the Coulombic one. Partial analysis of the PIXEL calculations was also carried out to identify pairs of molecules within the crystal framework that contribute most to the total energy of the packing. Fig. 8 lists the symmetry operation, the specific close contacts and the individual energy components for each molecule pair. The identified molecule pairs, I to IX, are depicted in Figs. 4 to 7, together with appropriate views of the Hirshfeld surface. In the figures of the molecule pairs, the epimeric molecules are coloured green (MolA) and blue (MolB), the partner to the specific epimer in the molecular pair is coloured in standard element colours and any other relevant molecule is coloured grey.

Substructures I and II connect MolA with MolA (Table 3 and Fig. 4) and subtructures VIII and IX connect MolB with MolB (Table 3 and Fig. 7). There is a similarity between substructures I and VII, as well as between substructures II and IX. Pairs I and VII are made by $\mathrm{C}_{\text {arom }}-\mathrm{H} \cdots \mathrm{O}_{\text {oxo }}$ interactions that give two isoenergetic subsets for each pair $\left(\mathbf{I}_{\mathbf{a}} / \mathbf{I}_{\mathbf{b}}\right.$ and $\left.\mathbf{V I I}_{\mathbf{a}} / \mathbf{V I I}_{\mathbf{b}}\right)$. These pairs relate $\operatorname{Mol} \mathbf{A} \cdots \mathbf{M o l} \mathbf{A}$ and MolB $\cdots$ MolB in chains, as can be visualized in Figs. 4 and 7. The total energies for the substructures of pairs I and pairs VII differ by about $5 \mathrm{~kJ} \mathrm{~mol}^{-1}$ (higher value for substructure I) and this may be due to the presence of an additional $\mathrm{C}-\mathrm{H} \cdots \pi$ interaction in I that is not detected in VIII [VII?]. The similar substructures $\mathbf{I I}_{\mathbf{a}} / \mathbf{I I}_{\mathbf{b}}$ and $\mathbf{I} \mathbf{X}_{\mathbf{a}} / \mathbf{I} \mathbf{X}_{\mathbf{b}}$, are built utilizing similar $\mathbf{C}-$ $\mathrm{H} \cdots \mathrm{O}$ interactions, involving the $\mathrm{O}$ atom of the nitro group of ring $B$. Nevertheless, the total energies for those pairs also differ by about $5 \mathrm{~kJ} \mathrm{~mol}^{-1}$, this time with a higher value for pairs IX due to a higher contribution of the dispersion term.
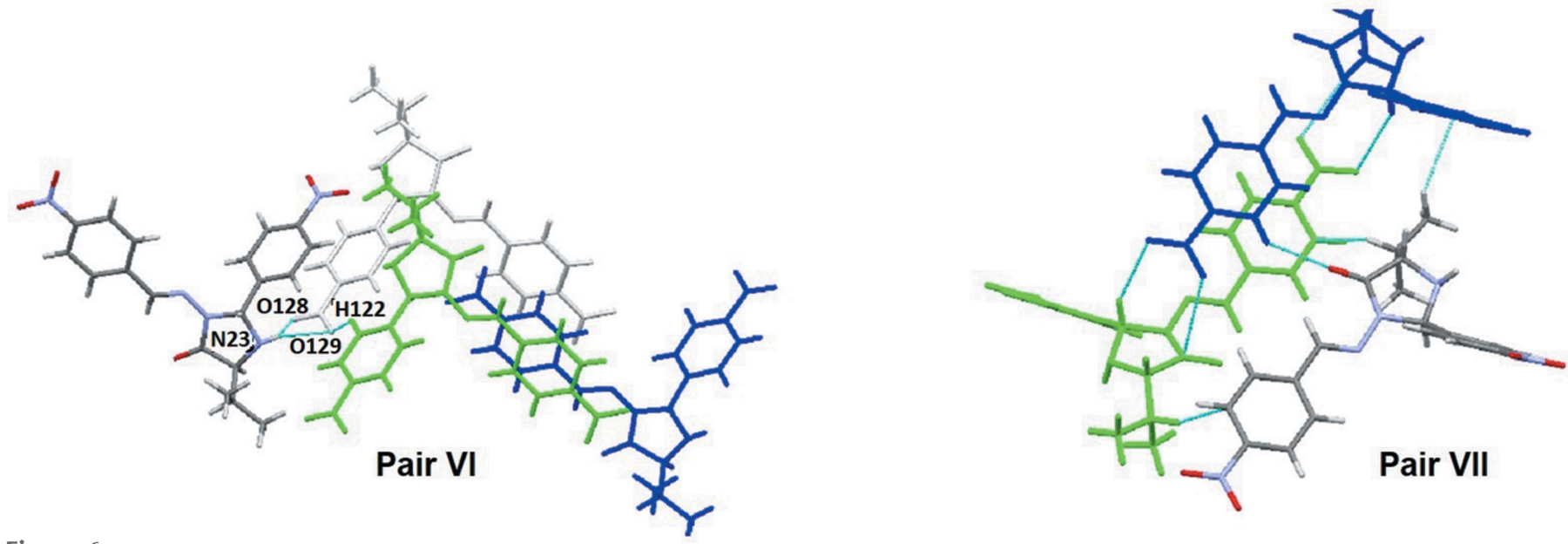

Figure 6

Molecular pairs involved in substructures VI and VII, made by the green stick molecule at $(x, y, z)$ with the [colour missing?] colour atoms molecules at $(-x, y+1, z+1)(\mathbf{V I})$ and $(x, y-1, z)(\mathbf{V I I})$. The grey molecule in pair VI is considered to act as the conduit for electronic interactions, while in pair VII, the conduit is considered to be MolB (blue) of the asymmetric unit. 
The molecules that constitute the asymmetric unit form the nonsymmetric dimeric substructure III. In this substructure, the nitro $\mathrm{O}$ atoms of ring $A$ act as acceptors in both molecules, but they interact with different $\mathrm{H}$ atoms, e.g. (i) a methyl $\mathrm{H}$ atom to form the $\mathrm{O} 138 \cdots \mathrm{H} 24 D-\mathrm{C} 243$ hydrogen bond in the MolA $\cdots$ MolB contact and (ii) an $\mathrm{H}$ atom of the imidazoline ring thereby generating an $\mathrm{O} 239 \cdots \mathrm{H} 12-\mathrm{C} 12$ hydrogen bond in the MolB $\cdots$ MolA contact (see Fig. 5).

In substructure $\mathbf{I V}$, the $\mathrm{N}-\mathrm{H}$ hydrogen of MolB makes a bifurcated hydrogen-bond interaction with both $\mathrm{O}$ atoms of the nitro group located in ring $B$ of MolA, e.g. O129 $\cdots \mathrm{H} 23-$ $\mathrm{N} 23$ and $\mathrm{O} 128 \cdots \mathrm{H} 23-\mathrm{N} 23$ (see pair IV in Fig. 5). This substructure, according to the model used for the calculation of interactions energies, contributes the highest amount of energy to the stabilization of the crystal packing. In the substructure made by pair $\mathbf{V}$, atom O139 of MolA acts as an acceptor for atom H226 of MolB (see Fig. 7). This layout permits a supramolecular arrangement where aromatic rings appear to stack, but the Hirshfeld surface (HS) analysis did not reveal spots related to C $\cdots$ C close contacts that are typical of the $\pi-\pi$ interactions.

Finally, two more substructures have been identified as energetically important in the stabilization of the supramolecular structure for 1. Molecular pairs involved in substructures VI and VII, relate the molecule at $(x, y, z)$ with the molecules at $(-x, y+1, z+1)$ (for VI) and $(x, y+1, z)$ (for VII). Although those molecules are not connected in a classical way, the pairs make a significant contribution to the lattice stabilization energy, i.e. -32.5 and $-25.9 \mathrm{~kJ} \mathrm{~mol}^{-1}$, respectively, for VI and VII. These pairs are depicted in Fig. 6,
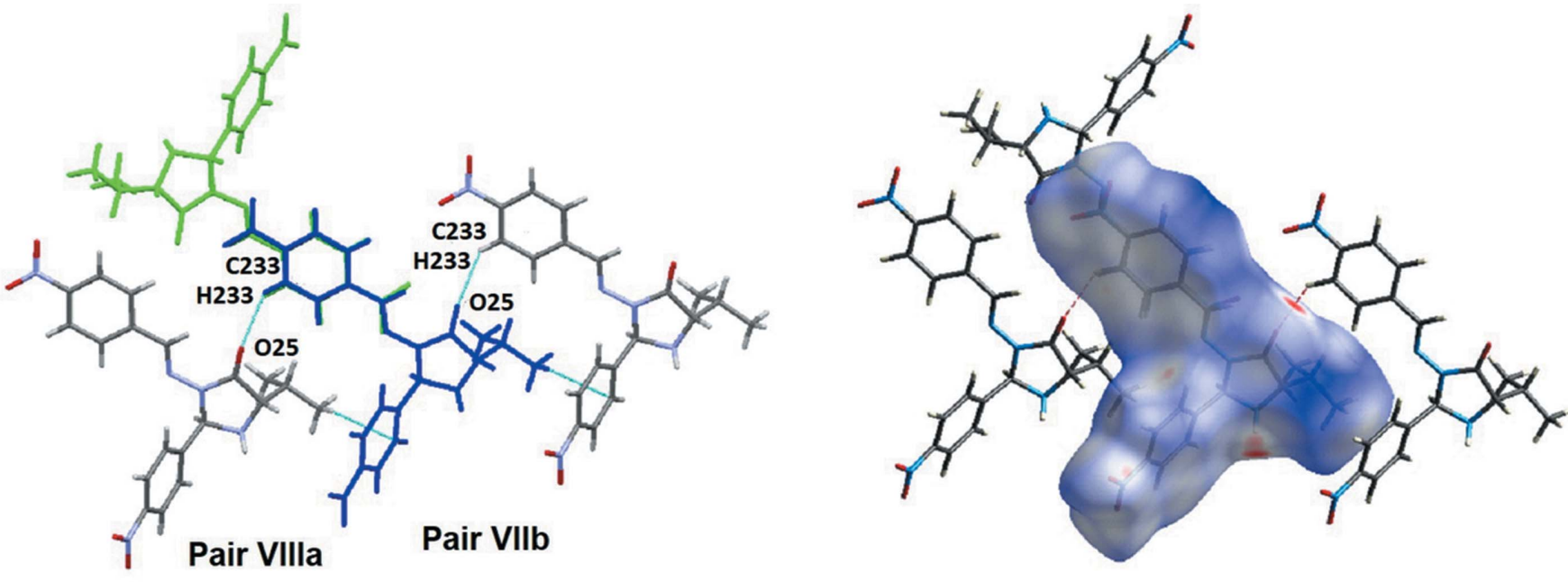

Pairs VIII
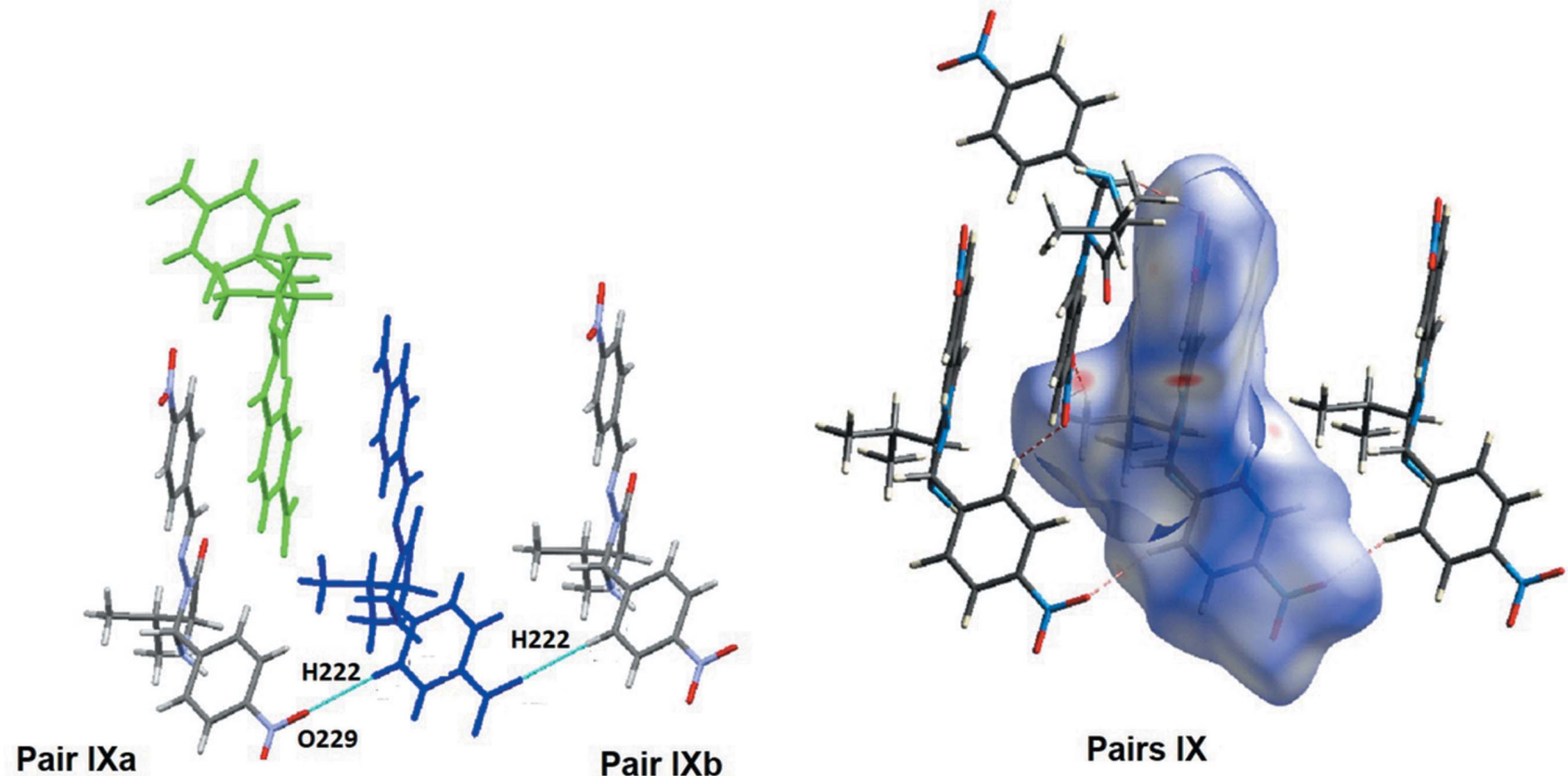

Pairs IX

Figure 7

The molecular pairs involved in substructures VII and IX. The figure also depicts the Hirshfeld surface images. 


\begin{tabular}{|c|c|c|c|c|c|c|c|}
\hline $\begin{array}{l}\text { Sub- } \\
\text { Structure }\end{array}$ & $\begin{array}{l}\text { molecular pairs } \\
\text { (Symmetry code) }\end{array}$ & Contacts & $\begin{array}{c}E_{\text {wat }} \\
(\text { (kJ.mol }\end{array}$ & $\begin{array}{c}E_{\text {easl }} \\
(\text { (kJJ.mol's) }\end{array}$ & $\begin{array}{c}E_{p \mathrm{pl}} \\
\left(\mathrm{kJJ} \cdot \mathrm{mol}^{4}\right)\end{array}$ & $\begin{array}{c}E_{\text {tas }} \\
\left(\text { (kJJ.mol }{ }^{4}\right)\end{array}$ & 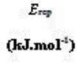 \\
\hline \multirow[t]{2}{*}{$\mathbf{L}(A \cdots A)$} & $x,-1+y, z$ & $\mathrm{C}-\mathrm{H} \cdots \pi$ & & & & & \\
\hline & & $\mathrm{C} 133-\mathrm{H} 133 \cdots \mathrm{O} 15$ & -33.1 & -23.1 & -10.6 & -44.5 & 44.4 \\
\hline \multirow[t]{2}{*}{ Ib $(A \cdots A)$} & $x, 1+y, z$ & $\mathrm{C}-\mathrm{H} \cdots \pi$ & & & & & \\
\hline & & $\mathrm{O} 15 \cdots \mathrm{H} 133-\mathrm{Cl} 33$ & -33.1 & -23.1 & -10.6 & -44.5 & 44.4 \\
\hline Il $(A \cdots A)$ & $-1+x, y, z$ & $\mathrm{C} 122-\mathrm{H} 122 \cdots 0129$ & -15.2 & -2.9 & -4.1 & -20.8 & 12.6 \\
\hline mb $(A \cdots A)$ & $1+x, y, z$ & $\mathrm{O} 129 \cdots \mathrm{H} 122-\mathrm{C} 122$ & -15.2 & -2.9 & -4.1 & -20.8 & 12.6 \\
\hline \multirow[t]{2}{*}{ 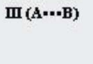 } & $x, y, z$ & $\mathrm{O} 138 \cdots \mathrm{H} 24 \mathrm{D}-\mathrm{C} 243$ & & -26.9 & -8.3 & -58.3 & 47.2 \\
\hline & & $\mathrm{C} 12-\mathrm{H} 12 \cdots 0239$ & -46.2 & & & & \\
\hline \multirow[t]{2}{*}{ 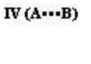 } & $\begin{array}{l}-1+x, 1+y,-1+ \\
z\end{array}$ & $\mathrm{O} 129 \cdots \mathrm{H} 23-\mathrm{N} 23$ & -53.8 & -28.8 & -11.1 & -46.6 & 33.8 \\
\hline & & $\mathrm{O} 128 \cdots \mathrm{H} 23-\mathrm{N} 23$ & & & & & \\
\hline$v(A \cdots B)$ & $-1+x, y, z$ & $\mathrm{O} 139 \cdots \mathrm{H} 226-\mathrm{C} 226$ & -46.7 & -27.9 & -9.0 & -53.9 & 44.0 \\
\hline vI $(A \cdots B)$ & $-x, 1+y, 1+z$ & $\cdots+$ & -32.5 & -13.7 & -7.2 & -37.4 & 25.8 \\
\hline VII $(A \cdots B)$ & $x, 1+y, z$ & $\cdots$ & -25.9 & -7.4 & -6.1 & -37.6 & 25.2 \\
\hline $\begin{array}{c}\mathrm{vII} \\
(\mathrm{B} \cdot \mathrm{B})\end{array}$ & $x,-1+y_{2} z$ & $\mathrm{C} 233-\mathrm{H} 233 \cdots \mathrm{O} 25$ & -28.0 & -17.3 & -6.0 & -27.2 & 22.4 \\
\hline 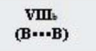 & $x, 1+y, z$ & $\mathrm{O} 25 \cdots \mathrm{H} 233-\mathrm{C} 233$ & -28.0 & -17.3 & -6.0 & -27.2 & 22.4 \\
\hline $\mathrm{LX},(\mathrm{B} \cdots \mathrm{B})$ & $I-x, y, z$ & $\mathrm{C} 222-\mathrm{H} 222 \cdots \mathrm{O} 229$ & -21.3 & -3.9 & -3.7 & -25.6 & 12.0 \\
\hline $\mathrm{KX},(\mathrm{B} \cdots \mathrm{B})$ & $1+x_{1}, y, z$ & $\mathrm{O} 229 \cdots \mathrm{H} 222-\mathrm{C} 222$ & -21.3 & -3.9 & -3.7 & -25.6 & 12.0 \\
\hline
\end{tabular}

Figure 8

Energies, close contacts and symmetry codes of the molecule pairs. A $\cdots A$ stands for MolA $\cdots$ MolA complexes, B $\cdots$ B for MolB $\cdots$ MolB complexes and A $\cdots$ B for MolA $\cdots$ MolB.

with the grey molecule in pair VI shown in order to clarify a possible path explaining the electronic interactions, while in pair VII, the those interactions are made via molB of the asymmetric unit.

Fig. 9 shows the fingerprint (FP) plots for MolA and MolB. The FP plots show two pairs of spikes pointing south-west and ending at $(1.2 ; 0.9 / 0.9 ; 1.2)$ that are due to $\mathrm{O} \cdots \mathrm{H} / \mathrm{H} \cdot \cdots \mathrm{O}$ close contacts, the light blue in the middle is due to the $\mathrm{H} \cdots \mathrm{H}$ and C. . C close contacts. The percentages for atom-atom contacts were taken from the FP plots and are given in Table 4. These percentages are similar for both molecules with an exception made for the $\mathrm{O} \cdots \mathrm{H}$ contacts that are smaller in MolB and the $\mathrm{N} \cdot \mathrm{H}$ and $\mathrm{H} \cdots \mathrm{H}$ contacts that are higher in MolA.

\section{Database survey}

A search of the Cambridge Structural Database (CSD, Version 5.39, August 2018 update; Groom et al., 2016) was carried out. The closest structure in the database to that of $\mathbf{1}$ is the 1:1 epimeric mixture of 5-isobutyl-2-(2-nitrophenyl)-3(phenylamino)imidazolidin-4-one (CSD refcode VAQZUJ; Verardo et al., 2003); this compound was also formed from a chiral reagent on reaction with a carbonyl compound. Other structures with a more remote relationship to 1 are $4-[(2 S, 4 S)$ 4-benzyl-1-methyl-5-oxoimidazolidin-2-yl]benzonitrile (ZAZKUI; Brase et al., 2012), (2S,5S)-5-benzyl-2-(4-fluorophenyl)3-methylimidazolidin-4-one (ZAZKOC; Brase et al., 2012), 3-benzyl-5-methyl-4-oxo-2-phenylimidazolidin-1-ium chloride (QITMIP; Nieger, 2000), 2-tert-butyl-3-methyl-4-oxo-5-(pentafluorobenzyl)imidazolidin-1-ium chloride (LUGTAK; Holland

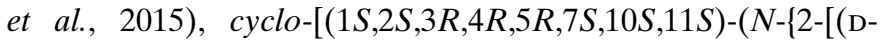

Table 5

Experimental details.

\begin{tabular}{ll}
\hline Crystal data & \\
Chemical formula & $\mathrm{C}_{19} \mathrm{H}_{19} \mathrm{~N}_{5} \mathrm{O}_{5}$ \\
$M_{\mathrm{r}}$ & 397.39 \\
Crystal system, space group & Triclinic, $P 1$ \\
Temperature (K) & 100 \\
$a, b, c(\AA)$ & $6.9346(1), 8.4380(2), 16.6963(5)$ \\
$\left.\alpha, \beta \gamma^{\circ}\right)$ & $79.826(2), 89.848(2), 80.488(2)$ \\
$V\left(\AA^{3}\right)$ & $948.03(4)$ \\
$Z$ & 2 \\
Radiation type & $\mathrm{Cu} \mathrm{K \alpha}$ \\
$\mu\left(\mathrm{mm}^{-1}\right)$ & 0.87 \\
Crystal size $(\mathrm{mm})$ & $0.15 \times 0.10 \times 0.08$ \\
&
\end{tabular}

Data collection

Diffractometer

Rigaku 007HF equipped with Varimax confocal mirrors and an C11 goniometer and HyPix 6000 detector

Absorption correction

Multi-scan (CrysAlis PRO; Rigaku OD, 2017)

$T_{\min }, T_{\max }$

No. of measured, independent and observed $[I>2 \sigma(I)]$ reflections

$R_{\text {int }}$

$(\sin \theta / \lambda)_{\max }\left(\AA^{-1}\right)$

$.876,1.000$

$17290,5885,5634$

0.032

0.602

Refinement

$R\left[F^{2}>2 \sigma\left(F^{2}\right)\right], w R\left(F^{2}\right), S$

No. of reflections

No. of parameters

No. of restraints

$\mathrm{H}$-atom treatment

$\Delta \rho_{\max }, \Delta \rho_{\min }\left(\mathrm{e} \AA^{-3}\right)$

Absolute structure

$$
\begin{aligned}
& 0.031,0.089,1.06 \\
& 5885 \\
& 535 \\
& 3 \\
& \text { H atoms treated by a mixture of } \\
& \quad \text { independent and constrained } \\
& \quad \text { refinement } \\
& 0.18,-0.15 \\
& \text { Flack } x \text { determined using } 2216 \\
& \quad \text { quotients }\left[\left(I^{+}\right)-\left(I^{-}\right)\right] / \\
& \quad\left[\left(I^{+}\right)+\left(I^{-}\right)\right](\text {Parsons } \text { et al., } 2013) \\
& 0.06(12)
\end{aligned}
$$

Absolute structure parameter

Computer programs: CrysAlis PRO (Rigaku OD, 2017), OSCAIL (McArdle et al., 2004), SHELXT (Sheldrick, 2015a), ShelXle (Hübschle et al., 2011), SHELXL2017 (Sheldrick, 2015b), Mercury (Macrae et al., 2008), SHELXL2017 (Sheldrick, 2015b) and PLATON (Spek, 2009).

galactopentitol-1-yl)-4-(4-hydroxybenzyl)-5-oxoimidazolin-1yl]acetyl \}glycyl)-L-phenylalanyl-L-leucine $4^{\prime}$-O $O$-ester (DACMAW; Kojic-Prodic et al., 2004) and 4-[(2S,4S)-4-isopropyl5-oxo-3-(3-oxobutyl)-1-(pyridin-2-yl)imidazolidin-2-yl]benzonitrile (NURSOJ; Xu et al., 2010).
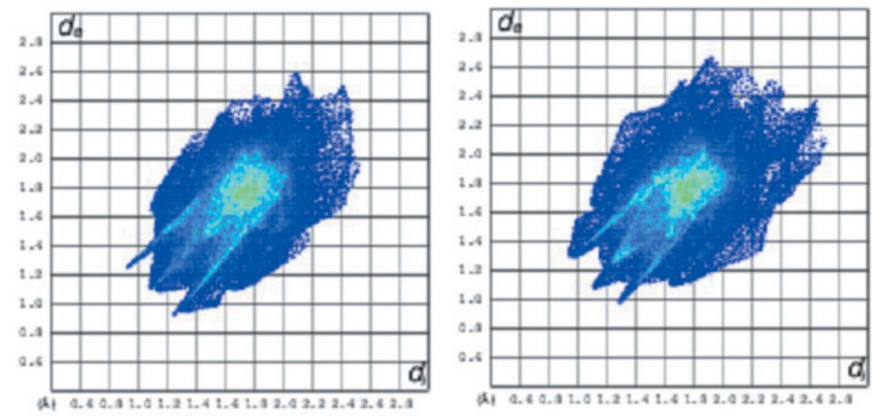

Figure 9

FP plots for MolA and MolB. The spikes are due to $\mathrm{O} \cdots \mathrm{H} / \mathrm{H} \cdots \mathrm{O}$ contacts and the outer ones due to the $\mathrm{N} \cdots \mathrm{H} \cdots \mathrm{N}$ contacts. 


\section{Synthesis and crystallization}

L-Valine (2) was converted to 2(S)-amino-3-methyl-1-oxobutanehydrazine (3) in two stages, as outlined in Scheme 1.

To a stirred solution of $\mathbf{3}(1 \mathrm{mmol})$ in ethanol $(10 \mathrm{ml})$ was added 4-nitrobenzaldehyde $(2.2 \mathrm{mmol})$. The reaction mixture was stirred for $20 \mathrm{~h}$ at $351 \mathrm{~K}$ and rotary evaporated. The residue was purified by column chromatography using a mixture of 9.7:0.3 ( $v / v)$ dichloromethane-methanol as eluent. Further purification was achieved by crystallization from ethanol. The crystal of $\mathbf{1}$ used in the structure determination was obtained by slow evaporation of an ethanol solution at room temperature.

M.p. 411-414 K. ${ }^{1} \mathrm{H}$ NMR (400 MHz, DMSO- $\left.d_{6}\right): \delta 0.96$ (6H, $m, \mathrm{Me}), 0.97(6 \mathrm{H}, m, \mathrm{Me}), 1.42(2 \mathrm{H}, m), 2.00(1 \mathrm{H}, m), 2.09$ $(1 \mathrm{H}, m), 4.06(2 \mathrm{H}, m), 7.66-7.71(4 \mathrm{H}, m), 7.82-7.85(4 \mathrm{H}, m)$, $8.422-8.48(8 \mathrm{H}, m)$.

${ }^{13} \mathrm{C}$ NMR (100 MHz, DMSO- $\left.d_{6}\right): \delta 17.2,17.4,18.9,29.9,30.3$, $61.8,62.53,124.0,123.7,128.1,128.1,128.3,128.9,140.2,1140.1$, 146.2, 146.3, 147.7, 148.2, 148.7, 171.1, 171.6. IR $\left(\mathrm{KBr}, \mathrm{cm}^{-1}\right): v$ $3015(b r), 1670,1518,1337$.

\section{Refinement}

Crystal data, data collection and structure refinement details are summarized in Table 5. $\mathrm{H}$ atoms attached to $\mathrm{C}$ atoms were refined as riding atoms at calculated positions. That attached to the $\mathrm{N}$ atom was refined.

\section{Acknowledgements}

The authors thank the staff at the National Crystallographic Service, University of Southampton (Coles \& Gale, 2012), for the data collection, help and advice.

\section{References}

Barrow, J. C., Rittle, K. E., Ngo, P. L., Selnick, H. G., Graham, S. L., Pitzenberger, S. M., McGaughey, G. B., Colussi, D., Lai, M. T., Huang, Q., Tugusheva, K., Espesth, A. S., Simon, A. J. K., Munishi, S. K. \& Vacca, J. P. (2007). ChemMedChem, 2, 995-999.

Blackmore, T. R. \& Thompson, P. E. (2011). Heterocycles, 83, $1953-$ 1975.

Brase, S., Volz, N., Glaser, F. \& Nieger, M. (2012). Beilstein J. Org. Chem, 8, 1385-1392.

Catalano, A., Carocci, A., Lentini, G., Di Mola, A., Bruno, C. \& Francini, C. (2011). Heterocycl. Chem. 48, 261-266.

Coles, S. J. \& Gale, P. A. (2012). Chem. Sci. 3, 683-689.

Cremer, D. \& Pople, J. A. (1975). J. Am. Chem. Soc. 97, 1354-1358.

Elrod, D. B. \& Worley, S. D. (1999). J. Bioact. Compat. Pol. 14, 258 269.

Eyilcim, O., Issever, S., Ocal, N., Gronert, S. \& Erden, I. (2018). Tetrahedron Lett. 59, 3674-3677.
Gavezzotti, A. (2003). J. Phys. Chem. B, 107, 2344-2353.

Gavezzotti, A. (2008). Mol. Phys. 106, 1473-1485.

Gomes, P., Araujo, M. J., Rodfrigues, M., Vale, N., Azevedo, Z., Iley, J., Chambel, P., Morais, J. \& Moreira, R. (2004). Tetrahedron, 60, 5551-5562.

Groom, C. R., Bruno, I. J., Lightfoot, M. P. \& Ward, S. C. (2016). Acta Cryst. B72, 171-179.

Guerra, A. S. H. D., Malta, D. J. D., Laranjeira, L. P. M., Maia, M. B. S., Colaco, N. C., de Lima, M. D. A., Galdino, S. L., Pitta, I. D. \& Goncalves-Silva, T. (2011). Int. J. Immunopharmacol. 11, 18161822.

Holland, M. C., Metternich, J. B., Daniliuc, C., Schweizer, W. C. \& Gilmour, R. (2015). Chem. Eur. J. 21, 10031-10038.

Hübschle, C. B., Sheldrick, G. M. \& Dittrich, B. (2011). J. Appl. Cryst. 44, 1281-1284.

Kojic-Prodic, B., Peric, B., Roscic, M., Novak, P. \& Horvat, S. (2004). J. Pept. Sci. 10, 47-55.

Li, J. Z., Zhang, Z. F. \& Fan, E. K. (2004). Tetrahedron Lett. 45, $1267-$ 1284.

Lin, Z., Chen, Z., Yang, G. \& Lu, C. (2013). Catal. Commun. 35, 105.

Macrae, C. F., Bruno, I. J., Chisholm, J. A., Edgington, P. R., McCabe, P., Pidcock, E., Rodriguez-Monge, L., Taylor, R., van de Streek, J. \& Wood, P. A. (2008). J. Appl. Cryst. 41, 466-470.

McArdle, P., Gilligan, K., Cunningham, D., Dark, R. \& Mahon, M. (2004). CrystEngComm, 6, 300-309.

Mondini, S., Puglisi, A., Benaglia, M., Ramella, D., Drago, C., Ferretti, A. M. \& Ponti, A. (2013). J. Nanopart. Res. 15, article no. UNSP 2025.

Nieger, M. (2000). CSD Communication (Private Communication). CCDC, Cambridge, England.

Parsons, S., Flack, H. D. \& Wagner, T. (2013). Acta Cryst. B69, 249259.

Puglisi, A., Benaglia, M., Annunziata, R., Chiroli, V., Porta, R. \& Gervasini, A. (2013). J. Org. Chem. 78, 11326-11334.

Rigaku OD (2017). CryAlis PRO. Rigaku Oxford Diffraction Ltd, Yarnton, Oxfordshire, England.

Seebach, D., Groselj, U., Baldine, D. M., Schweizer, W. B. \& Beck, A. K. (2008). Helv. Chim. Acta, 91, 1999-2034.

Sheldrick, G. M. (2015a). Acta Cryst. A71, 3-8.

Sheldrick, G. M. (2015b). Acta Cryst. C71, 3-8.

Spackman, M. A. \& Jayatilaka, D. (2009). CrystEngComm, 11, 19-32.

Spackman, M. A. \& McKinnon, J. J. (2002). CrystEngComm, 4, 378392.

Spek, A. L. (2009). Acta Cryst. D65, 148-155.

Vale, N., Matos, J., Moreira, R. \& Gomes, T. (2008). Tetrahedron, 64, 11144-11149.

Vale, N., Nogueira, F., do Rosario, V. E., Gomes, P. \& Moreira, R. (2009). Eur. J. Med. Chem. 44, 2506-2516.

Verardo, G., Geatti, P., Martinuzzi, P., Merli, M. \& Toniutti, N. (2003). Eur. J. Org. Chem. 2003, 3840-2849.

Wolff, S. K., Grimwood, D. I., McKinnon, J. J., Turner, M. J., Jayatilaka, D. \& Spackman, M. A. (2012). CrystalExplorer. Version 3.1. The University of Western Australia.

Xu, Z., Buechler, T., Wheeler, K. \& Wang, H. (2010). Chem. Eur. J. 16, 2972-2976. 


\section{supporting information}

Acta Cryst. (2019). E75, 1774-1782 [https://doi.org/10.1107/S2056989019013938]

Crystal structure, Hirshfeld surface analysis and PIXEL calculations of a 1:1

epimeric mixture of 3-[(4-nitrobenzylidene)amino]-2(R,S)-(4-nitrophenyl)-5(S)-(propan-2-yl)imidazolidin-4-one

Ligia R. Gomes, John Nicolson Low, James L. Wardell, Marcus V. N. de Souza and Cristiane F. da Costa

Computing details

Data collection: CrysAlis PRO (Rigaku OD, 2017); cell refinement: CrysAlis PRO (Rigaku OD, 2017); data reduction: CrysAlis PRO (Rigaku OD, 2017); program(s) used to solve structure: OSCAIL (McArdle et al., 2004) and SHELXT (Sheldrick, 2015a); program(s) used to refine structure: OSCAIL (McArdle et al., 2004), ShelXle (Hübschle et al., 2011) and SHELXL2017 (Sheldrick, 2015b); molecular graphics: Mercury (Macrae et al., 2008); software used to prepare material for publication: OSCAIL (McArdle et al., 2004), SHELXL2017 (Sheldrick, 2015b) and PLATON (Spek, 2009).

3-[(4-Nitrobenzylidene)amino]-2(R,S)-(4-nitrophenyl)-5(S)-(propan-2-yl)imidazolidin-4-one

Crystal data

$\mathrm{C}_{19} \mathrm{H}_{19} \mathrm{~N}_{5} \mathrm{O}_{5}$

$M_{r}=397.39$

Triclinic, $P 1$

$a=6.9346(1) \AA$

$b=8.4380(2) \AA$

$c=16.6963(5) \AA$

$\alpha=79.826(2)^{\circ}$

$\beta=89.848(2)^{\circ}$

$\gamma=80.488(2)^{\circ}$

$V=948.03(4) \AA^{3}$

\section{Data collection}

Rigaku 007HF equipped with Varimax confocal mirrors and an $\mathrm{C} 11$ goniometer and HyPix 6000 detector diffractometer

Radiation source: Rotating anode, Rigaku 007 $\mathrm{HF}$

Varimax focusing mirrors monochromator Detector resolution: 10 pixels $\mathrm{mm}^{-1}$ profile data from $\omega$-scans
$Z=2$

$F(000)=416$

$D_{\mathrm{x}}=1.392 \mathrm{Mg} \mathrm{m}^{-3}$

$\mathrm{Cu} K \alpha$ radiation, $\lambda=1.54178 \AA$

Cell parameters from 10799 reflections

$\theta=2.6-70.2^{\circ}$

$\mu=0.87 \mathrm{~mm}^{-1}$

$T=100 \mathrm{~K}$

Block, yellow

$0.15 \times 0.10 \times 0.08 \mathrm{~mm}$

Absorption correction: multi-scan

(CrysAlis PRO; Rigaku OD, 2017)

$T_{\min }=0.876, T_{\max }=1.000$

17290 measured reflections

5885 independent reflections

5634 reflections with $I>2 \sigma(I)$

$R_{\text {int }}=0.032$

$\theta_{\max }=68.2^{\circ}, \theta_{\min }=2.7^{\circ}$

$h=-8 \rightarrow 8$

$k=-10 \rightarrow 10$

$l=-20 \rightarrow 20$ 


\section{Refinement}

Refinement on $F^{2}$

Least-squares matrix: full

$R\left[F^{2}>2 \sigma\left(F^{2}\right)\right]=0.031$

$w R\left(F^{2}\right)=0.089$

$S=1.06$

5885 reflections

535 parameters

3 restraints

Hydrogen site location: mixed
$\mathrm{H}$ atoms treated by a mixture of independent and constrained refinement

$w=1 /\left[\sigma^{2}\left(F_{\mathrm{o}}^{2}\right)+(0.0635 P)^{2}+0.0162 P\right]$

where $P=\left(F_{\mathrm{o}}^{2}+2 F_{\mathrm{c}}^{2}\right) / 3$

$(\Delta / \sigma)_{\max }<0.001$

$\Delta \rho_{\max }=0.18 \mathrm{e} \AA^{-3}$

$\Delta \rho_{\min }=-0.15$ e $\AA^{-3}$

Absolute structure: Flack $x$ determined using 2216 quotients [(I+)-(I-)]/[(I+)+(I-)] (Parsons et al., 2013)

Absolute structure parameter: 0.06 (12)

\section{Special details}

Geometry. All esds (except the esd in the dihedral angle between two 1.s. planes) are estimated using the full covariance matrix. The cell esds are taken into account individually in the estimation of esds in distances, angles and torsion angles; correlations between esds in cell parameters are only used when they are defined by crystal symmetry. An approximate (isotropic) treatment of cell esds is used for estimating esds involving 1.s. planes.

Fractional atomic coordinates and isotropic or equivalent isotropic displacement parameters $\left(\AA^{2}\right)$

\begin{tabular}{|c|c|c|c|c|}
\hline & $x$ & $y$ & $z$ & $U_{\text {iso }} * / U_{\text {eq }}$ \\
\hline $\mathrm{O} 15$ & $0.4298(3)$ & $1.1382(2)$ & $0.37596(10)$ & $0.0355(4)$ \\
\hline $\mathrm{O} 25$ & $0.7120(3)$ & $-0.1997(2)$ & $0.63494(11)$ & $0.0454(5)$ \\
\hline O128 & $0.0134(3)$ & $0.6977(3)$ & $-0.07548(12)$ & $0.0515(6)$ \\
\hline O129 & -0.2170 & $0.7084(3)$ & $0.01078(11)$ & $0.0445(5)$ \\
\hline O138 & $0.2174(3)$ & $0.1363(3)$ & $0.59026(13)$ & $0.0478(5)$ \\
\hline O139 & $0.1723(3)$ & $0.2713(3)$ & $0.68946(12)$ & $0.0496(5)$ \\
\hline $\mathrm{O} 228$ & $0.9876(3)$ & $0.2933(3)$ & $1.07358(13)$ & $0.0578(6)$ \\
\hline O229 & $1.2157(3)$ & $0.2968(3)$ & $0.98725(12)$ & $0.0476(5)$ \\
\hline $\mathrm{O} 238$ & $0.7903(3)$ & $0.8399(3)$ & $0.38544(13)$ & $0.0456(5)$ \\
\hline $\mathrm{O} 239$ & $0.8329(3)$ & $0.6925(3)$ & $0.29111(12)$ & $0.0487(5)$ \\
\hline N11 & $0.3637(3)$ & $0.9864(2)$ & $0.27940(11)$ & $0.0276(4)$ \\
\hline N13 & $0.4764(3)$ & $1.1352(3)$ & $0.16385(12)$ & $0.0306(4)$ \\
\hline H13 & $0.362(5)$ & $1.192(4)$ & $0.1427(18)$ & $0.034(7)^{*}$ \\
\hline $\mathrm{N} 21$ & $0.6624(3)$ & $-0.0012(3)$ & $0.71543(12)$ & $0.0302(4)$ \\
\hline $\mathrm{N} 23$ & $0.5744(3)$ & $-0.1541(3)$ & $0.83569(13)$ & $0.0353(5)$ \\
\hline $\mathrm{H} 23$ & $0.660(6)$ & $-0.187(5)$ & $0.877(2)$ & $0.058(10)^{*}$ \\
\hline N111 & $0.3401(3)$ & $0.8408(2)$ & $0.32899(11)$ & $0.0270(4)$ \\
\hline N211 & $0.6703(3)$ & $0.1435(2)$ & $0.66255(11)$ & $0.0288(4)$ \\
\hline $\mathrm{C} 12$ & $0.4363(3)$ & $0.9729(3)$ & $0.19724(14)$ & $0.0277(5)$ \\
\hline H12 & 0.562548 & 0.894474 & 0.203010 & $0.033^{*}$ \\
\hline $\mathrm{C} 14$ & $0.5332(3)$ & $1.2011(3)$ & $0.23511(13)$ & $0.0286(5)$ \\
\hline H14 & 0.678098 & 1.168896 & 0.243608 & $0.034 *$ \\
\hline $\mathrm{C} 15$ & $0.4376(3)$ & $1.1108(3)$ & $0.30696(13)$ & $0.0287(5)$ \\
\hline $\mathrm{C} 22$ & $0.5853(4)$ & $0.0145(3)$ & $0.79628(14)$ & $0.0298(5)$ \\
\hline $\mathrm{H} 22$ & 0.450305 & 0.079596 & 0.789649 & $0.036^{*}$ \\
\hline $\mathrm{C} 24$ & $0.6057(4)$ & $-0.2618(3)$ & $0.77444(14)$ & $0.0335(5)$ \\
\hline $\mathrm{H} 24$ & 0.715645 & -0.353217 & 0.793820 & $0.040 *$ \\
\hline $\mathrm{C} 25$ & $0.6675(4)$ & $-0.1559(3)$ & $0.69896(15)$ & $0.0348(5)$ \\
\hline
\end{tabular}




\begin{tabular}{|c|c|c|c|c|}
\hline C112 & $0.2670(3)$ & $0.8488(3)$ & $0.39906(14)$ & $0.0279(5)$ \\
\hline H112 & 0.225845 & 0.951561 & 0.414946 & $0.033 *$ \\
\hline $\mathrm{C} 121$ & $0.2980(3)$ & $0.9158(3)$ & $0.14341(14)$ & $0.0262(5)$ \\
\hline $\mathrm{C} 122$ & $0.3699(4)$ & $0.8750(3)$ & $0.07013(14)$ & $0.0308(5)$ \\
\hline H122 & 0.499729 & 0.887882 & 0.055715 & $0.037 *$ \\
\hline $\mathrm{C} 123$ & $0.2556(4)$ & $0.8164(3)$ & $0.01828(14)$ & $0.0320(5)$ \\
\hline H123 & 0.304016 & 0.790033 & -0.031853 & $0.038^{*}$ \\
\hline C124 & $0.0687(4)$ & $0.7973(3)$ & $0.04175(14)$ & $0.0293(5)$ \\
\hline $\mathrm{C} 125$ & $-0.0089(3)$ & $0.8388(3)$ & $0.11285(14)$ & $0.0312(5)$ \\
\hline H125 & -0.138837 & 0.825399 & 0.126857 & $0.037^{*}$ \\
\hline C126 & 0.1067 (4) & 0.9007 (3) & $0.16358(14)$ & $0.0313(5)$ \\
\hline H126 & 0.054796 & 0.932735 & 0.212100 & $0.038^{*}$ \\
\hline N127 & $-0.0521(3)$ & $0.7287(3)$ & $-0.01117(12)$ & $0.0323(5)$ \\
\hline $\mathrm{C} 131$ & $0.2478(3)$ & $0.6970(3)$ & $0.45425(13)$ & $0.0261(5)$ \\
\hline C132 & $0.2849(3)$ & $0.5462(3)$ & $0.42896(14)$ & $0.0264(5)$ \\
\hline H132 & 0.320914 & 0.541502 & 0.374383 & $0.032 *$ \\
\hline $\mathrm{C} 133$ & $0.2700(3)$ & $0.4040(3)$ & $0.48178(14)$ & $0.0287(5)$ \\
\hline H133 & 0.295345 & 0.301262 & 0.464512 & $0.034^{*}$ \\
\hline C134 & $0.2168(3)$ & $0.4152(3)$ & $0.56112(14)$ & $0.0302(5)$ \\
\hline $\mathrm{C} 135$ & $0.1772(3)$ & $0.5612(3)$ & $0.58830(14)$ & $0.0318(5)$ \\
\hline H135 & 0.140140 & 0.564508 & 0.642882 & $0.038^{*}$ \\
\hline $\mathrm{C} 136$ & $0.1922(3)$ & $0.7036(3)$ & $0.53455(14)$ & $0.0307(5)$ \\
\hline H136 & 0.164724 & 0.805932 & 0.552131 & $0.037^{*}$ \\
\hline N137 & $0.2007(3)$ & $0.2631(3)$ & $0.61757(13)$ & $0.0378(5)$ \\
\hline C141 & $0.4849(4)$ & $1.3855(3)$ & $0.22729(14)$ & $0.0324(5)$ \\
\hline H141 & 0.522467 & 1.411918 & 0.280582 & $0.039 *$ \\
\hline C142 & $0.6066(5)$ & $1.4719(4)$ & $0.16285(18)$ & $0.0451(7)$ \\
\hline H14D & 0.580595 & 1.589617 & 0.163030 & $0.068 *$ \\
\hline H14E & 0.571639 & 1.451708 & 0.109156 & $0.068^{*}$ \\
\hline $\mathrm{H} 14 \mathrm{~F}$ & 0.745792 & 1.430079 & 0.174926 & $0.068^{*}$ \\
\hline C143 & $0.2666(4)$ & $1.4489(3)$ & $0.21372(16)$ & $0.0387(6)$ \\
\hline $\mathrm{H} 14 \mathrm{~A}$ & 0.238790 & 1.563576 & 0.220178 & $0.058^{*}$ \\
\hline H14B & 0.193577 & 1.384089 & 0.253620 & $0.058^{*}$ \\
\hline $\mathrm{H} 14 \mathrm{C}$ & 0.227059 & 1.439805 & 0.158629 & $0.058^{*}$ \\
\hline $\mathrm{C} 212$ & $0.7367(3)$ & $0.1361(3)$ & $0.59108(15)$ & $0.0301(5)$ \\
\hline $\mathrm{H} 212$ & 0.777043 & 0.033090 & 0.575349 & $0.036^{*}$ \\
\hline $\mathrm{C} 221$ & $0.7088(3)$ & $0.0917(3)$ & $0.84770(14)$ & $0.0282(5)$ \\
\hline $\mathrm{C} 222$ & $0.6347(4)$ & $0.1260(3)$ & $0.92174(14)$ & $0.0299(5)$ \\
\hline $\mathrm{H} 222$ & 0.506428 & 0.107886 & 0.936016 & $0.036^{*}$ \\
\hline $\mathrm{C} 223$ & $0.7456(4)$ & $0.1858(3)$ & $0.97467(14)$ & $0.0308(5)$ \\
\hline $\mathrm{H} 223$ & 0.696374 & 0.206566 & 1.025638 & $0.037 *$ \\
\hline $\mathrm{C} 224$ & $0.9301(4)$ & $0.2146(3)$ & $0.95128(14)$ & $0.0286(5)$ \\
\hline $\mathrm{C} 225$ & $1.0058(4)$ & $0.1867(3)$ & $0.87724(15)$ & $0.0325(5)$ \\
\hline $\mathrm{H} 225$ & 1.131517 & 0.210277 & 0.862046 & $0.039 *$ \\
\hline $\mathrm{C} 226$ & $0.8942(3)$ & $0.1235(3)$ & $0.82574(14)$ & $0.0301(5)$ \\
\hline H226 & 0.944672 & 0.101824 & 0.775113 & $0.036^{*}$ \\
\hline N227 & $1.0519(3)$ & $0.2745(3)$ & $1.00771(12)$ & $0.0339(5)$ \\
\hline C231 & 0.7499 (3) & $0.2873(3)$ & $0.53383(13)$ & $0.0277(5)$ \\
\hline
\end{tabular}




$\begin{array}{lllll}\mathrm{C} 232 & 0.7186(3) & 0.4406(3) & 0.55683(14) & 0.0287(5) \\ \mathrm{H} 232 & 0.685933 & 0.449496 & 0.611332 & 0.034^{*} \\ \mathrm{C} 233 & 0.7347(3) & 0.5795(3) & 0.50108(15) & 0.0299(5) \\ \mathrm{H} 233 & 0.712742 & 0.683984 & 0.516467 & 0.036^{*} \\ \mathrm{C} 234 & 0.7840(3) & 0.5624(3) & 0.42183(15) & 0.0307(5) \\ \mathrm{C} 235 & 0.8170(3) & 0.4122(3) & 0.39713(14) & 0.0314(5) \\ \mathrm{H} 235 & 0.850887 & 0.403867 & 0.342684 & 0.038^{*} \\ \mathrm{C} 236 & 0.7993(3) & 0.2746(3) & 0.45354(14) & 0.0303(5) \\ \mathrm{H} 236 & 0.820955 & 0.170474 & 0.437723 & 0.036^{*} \\ \mathrm{~N} 237 & 0.8038(3) & 0.7084(3) & 0.36213(13) & 0.0366(5) \\ \mathrm{C} 241 & 0.4241(4) & -0.3336(3) & 0.75728(15) & 0.0345(5) \\ \mathrm{H} 241 & 0.445003 & -0.378380 & 0.705741 & 0.041^{*} \\ \mathrm{C} 242 & 0.3982(5) & -0.4738(4) & 0.82522(19) & 0.0455(7) \\ \mathrm{H} 24 \mathrm{~A} & 0.515569 & -0.557757 & 0.830591 & 0.068^{*} \\ \mathrm{H} 24 \mathrm{~B} & 0.284532 & -0.520913 & 0.812321 & 0.068^{*} \\ \mathrm{H} 24 \mathrm{C} & 0.377662 & -0.432928 & 0.876535 & 0.068^{*} \\ \mathrm{C} 243 & 0.2417(4) & -0.2027(3) & 0.74492(16) & 0.0369(5) \\ \mathrm{H} 24 \mathrm{D} & 0.259555 & -0.117069 & 0.698937 & 0.055^{*} \\ \mathrm{H} 24 \mathrm{E} & 0.219738 & -0.155144 & 0.794304 & 0.055^{*} \\ \mathrm{H} 24 \mathrm{~F} & 0.128424 & -0.251832 & 0.733575 & 0.055^{*}\end{array}$

Atomic displacement parameters $\left(\AA^{2}\right)$

\begin{tabular}{lllllll}
\hline & $U^{11}$ & $U^{22}$ & $U^{33}$ & $U^{12}$ & $U^{13}$ & $U^{23}$ \\
\hline O15 & $0.0480(10)$ & $0.0339(9)$ & $0.0271(8)$ & $-0.0136(8)$ & $-0.0009(7)$ & $-0.0057(7)$ \\
O25 & $0.0636(12)$ & $0.0408(11)$ & $0.0385(10)$ & $-0.0199(9)$ & $0.0130(9)$ & $-0.0150(8)$ \\
O128 & $0.0459(11)$ & $0.0821(16)$ & $0.0359(11)$ & $-0.0172(10)$ & $0.0023(8)$ & $-0.0293(11)$ \\
O129 & $0.0418(10)$ & $0.0597(13)$ & $0.0372(10)$ & $-0.0232(9)$ & $0.0006(8)$ & $-0.0087(9)$ \\
O138 & $0.0493(12)$ & $0.0346(11)$ & $0.0559(12)$ & $-0.0119(9)$ & $-0.0051(9)$ & $0.0066(9)$ \\
O139 & $0.0474(11)$ & $0.0619(13)$ & $0.0327(10)$ & $-0.0116(10)$ & $0.0032(8)$ & $0.0120(9)$ \\
O228 & $0.0529(12)$ & $0.0899(18)$ & $0.0419(11)$ & $-0.0211(12)$ & $0.0018(9)$ & $-0.0340(12)$ \\
O229 & $0.0443(11)$ & $0.0625(14)$ & $0.0433(11)$ & $-0.0252(10)$ & $-0.0014(9)$ & $-0.0134(10)$ \\
O238 & $0.0378(10)$ & $0.0405(11)$ & $0.0533(12)$ & $-0.0083(8)$ & $-0.0046(8)$ & $0.0074(9)$ \\
O239 & $0.0458(11)$ & $0.0592(13)$ & $0.0333(10)$ & $-0.0063(9)$ & $0.0048(8)$ & $0.0101(9)$ \\
N11 & $0.0356(10)$ & $0.0262(11)$ & $0.0222(9)$ & $-0.0108(8)$ & $0.0005(8)$ & $-0.0023(8)$ \\
N13 & $0.0390(11)$ & $0.0278(11)$ & $0.0261(10)$ & $-0.0118(9)$ & $-0.0003(8)$ & $-0.0016(8)$ \\
N21 & $0.0349(11)$ & $0.0332(12)$ & $0.0243(9)$ & $-0.0125(9)$ & $0.0008(8)$ & $-0.0039(8)$ \\
N23 & $0.0469(12)$ & $0.0353(12)$ & $0.0261(10)$ & $-0.0177(10)$ & $-0.0048(9)$ & $-0.0021(9)$ \\
N111 & $0.0300(10)$ & $0.0274(11)$ & $0.0238(10)$ & $-0.0099(8)$ & $-0.0039(7)$ & $-0.0002(8)$ \\
N211 & $0.0295(10)$ & $0.0339(11)$ & $0.0237(10)$ & $-0.0116(9)$ & $-0.0026(8)$ & $-0.0013(8)$ \\
C12 & $0.0321(12)$ & $0.0283(13)$ & $0.0228(11)$ & $-0.0074(10)$ & $0.0006(9)$ & $-0.0025(9)$ \\
C14 & $0.0310(11)$ & $0.0278(12)$ & $0.0274(11)$ & $-0.0077(9)$ & $-0.0021(9)$ & $-0.0032(9)$ \\
C15 & $0.0329(12)$ & $0.0258(12)$ & $0.0267(11)$ & $-0.0052(9)$ & $-0.0034(9)$ & $-0.0025(9)$ \\
C22 & $0.0325(12)$ & $0.0348(13)$ & $0.0226(11)$ & $-0.0112(10)$ & $0.0019(9)$ & $-0.0012(10)$ \\
C24 & $0.0371(13)$ & $0.0312(13)$ & $0.0314(12)$ & $-0.0073(10)$ & $-0.0026(10)$ & $-0.0018(9)$ \\
C25 & $0.0360(12)$ & $0.0358(14)$ & $0.0342(12)$ & $-0.0109(10)$ & $0.0010(10)$ & $-0.0060(10)$ \\
C112 & $0.0275(11)$ & $0.0307(12)$ & $0.0265(11)$ & $-0.0080(9)$ & $-0.0012(9)$ & $-0.0047(9)$ \\
C121 & $0.0338(12)$ & $0.0202(11)$ & $0.0231(11)$ & $-0.0057(9)$ & $-0.0006(9)$ & $0.0010(8)$ \\
& & & & & &
\end{tabular}




\begin{tabular}{|c|c|c|c|c|c|c|}
\hline $\mathrm{C} 122$ & $0.0350(12)$ & $0.0326(13)$ & $0.0253(12)$ & $-0.0106(10)$ & $0.0034(9)$ & $-0.0022(10)$ \\
\hline $\mathrm{C} 123$ & 0.0394 (13) & $0.0325(13)$ & $0.0247(12)$ & $-0.0093(10)$ & $0.0031(10)$ & $-0.0036(9)$ \\
\hline $\mathrm{C} 124$ & $0.0362(12)$ & $0.0261(12)$ & $0.0244(11)$ & $-0.0064(10)$ & $-0.0044(9)$ & $-0.0003(9)$ \\
\hline $\mathrm{C} 125$ & $0.0295(12)$ & $0.0357(13)$ & $0.0273(12)$ & $-0.0064(10)$ & $0.0001(9)$ & $-0.0022(10)$ \\
\hline C126 & $0.0352(12)$ & $0.0343(13)$ & $0.0238(11)$ & $-0.0045(10)$ & $-0.0002(9)$ & $-0.0045(9)$ \\
\hline N127 & $0.0360(11)$ & $0.0325(11)$ & $0.0286(11)$ & $-0.0083(9)$ & $-0.0026(8)$ & $-0.0030(8)$ \\
\hline C131 & $0.0226(11)$ & $0.0341(13)$ & $0.0226(11)$ & $-0.0088(10)$ & $-0.0028(8)$ & $-0.0037(9)$ \\
\hline C132 & $0.0254(11)$ & $0.0341(13)$ & $0.0209(10)$ & $-0.0095(9)$ & $-0.0005(8)$ & $-0.0043(9)$ \\
\hline C133 & $0.0229(11)$ & $0.0337(13)$ & $0.0306(12)$ & $-0.0081(10)$ & $-0.0035(9)$ & $-0.0058(10)$ \\
\hline $\mathrm{C} 134$ & $0.0227(11)$ & $0.0378(14)$ & $0.0278(11)$ & $-0.0097(10)$ & $-0.0037(9)$ & $0.0047(10)$ \\
\hline C135 & $0.0277(11)$ & $0.0458(16)$ & $0.0228(11)$ & $-0.0110(11)$ & $-0.0006(9)$ & $-0.0038(10)$ \\
\hline C136 & 0.0307 (12) & $0.0378(14)$ & $0.0256(11)$ & $-0.0095(10)$ & $0.0002(9)$ & $-0.0078(10)$ \\
\hline N137 & $0.0258(10)$ & $0.0467(15)$ & $0.0366(12)$ & $-0.0093(10)$ & $-0.0032(9)$ & $0.0067(10)$ \\
\hline C141 & $0.0403(13)$ & $0.0290(12)$ & $0.0290(11)$ & $-0.0094(10)$ & $-0.0022(9)$ & $-0.0046(9)$ \\
\hline C142 & $0.0623(18)$ & $0.0298(14)$ & $0.0442(15)$ & $-0.0159(13)$ & $0.0078(13)$ & $-0.0020(12)$ \\
\hline C143 & 0.0437 (14) & $0.0309(13)$ & $0.0402(13)$ & $-0.0031(11)$ & $-0.0100(11)$ & $-0.0058(10)$ \\
\hline $\mathrm{C} 212$ & $0.0301(11)$ & $0.0353(13)$ & $0.0274(12)$ & $-0.0114(10)$ & $-0.0006(9)$ & $-0.0071(10)$ \\
\hline C221 & $0.0336(12)$ & $0.0271(12)$ & $0.0233(11)$ & $-0.0074(10)$ & $-0.0015(9)$ & $-0.0008(9)$ \\
\hline C222 & $0.0325(12)$ & $0.0309(13)$ & $0.0260(12)$ & $-0.0089(10)$ & $0.0016(9)$ & $-0.0009(9)$ \\
\hline $\mathrm{C} 223$ & $0.0375(13)$ & $0.0326(13)$ & $0.0221(11)$ & $-0.0064(10)$ & $0.0014(9)$ & $-0.0034(9)$ \\
\hline $\mathrm{C} 224$ & $0.0374(12)$ & $0.0234(11)$ & $0.0245(11)$ & $-0.0074(10)$ & $-0.0044(9)$ & $-0.0012(9)$ \\
\hline $\mathrm{C} 225$ & $0.0333(12)$ & $0.0359(13)$ & $0.0296(12)$ & $-0.0111(10)$ & $0.0015(10)$ & $-0.0045(10)$ \\
\hline $\mathrm{C} 226$ & $0.0323(12)$ & $0.0347(13)$ & $0.0242(11)$ & $-0.0098(10)$ & $0.0025(9)$ & $-0.0038(9)$ \\
\hline N227 & $0.0400(12)$ & $0.0325(12)$ & $0.0293(11)$ & $-0.0056(9)$ & $-0.0053(9)$ & $-0.0058(9)$ \\
\hline $\mathrm{C} 231$ & $0.0224(11)$ & $0.0391(14)$ & $0.0230(11)$ & $-0.0099(10)$ & $-0.0018(9)$ & $-0.0049(10)$ \\
\hline $\mathrm{C} 232$ & $0.0235(11)$ & 0.0407 (14) & $0.0236(11)$ & $-0.0088(10)$ & $-0.0039(9)$ & $-0.0067(10)$ \\
\hline $\mathrm{C} 233$ & $0.0234(11)$ & $0.0355(14)$ & $0.0314(12)$ & $-0.0081(10)$ & $-0.0036(9)$ & $-0.0048(10)$ \\
\hline $\mathrm{C} 234$ & $0.0223(11)$ & $0.0414(14)$ & 0.0267 (11) & $-0.0086(10)$ & $-0.0037(9)$ & $0.0015(10)$ \\
\hline $\mathrm{C} 235$ & $0.0254(11)$ & $0.0476(15)$ & $0.0216(11)$ & $-0.0098(10)$ & $-0.0011(9)$ & $-0.0038(10)$ \\
\hline $\mathrm{C} 236$ & $0.0266(11)$ & $0.0406(14)$ & 0.0257 (11) & $-0.0110(10)$ & $-0.0008(9)$ & $-0.0068(10)$ \\
\hline N237 & $0.0253(10)$ & $0.0434(14)$ & $0.0364(12)$ & $-0.0071(9)$ & $-0.0013(8)$ & $0.0070(10)$ \\
\hline $\mathrm{C} 241$ & $0.0442(14)$ & $0.0300(13)$ & $0.0316(12)$ & $-0.0130(11)$ & $0.0002(10)$ & $-0.0051(10)$ \\
\hline $\mathrm{C} 242$ & $0.0566(17)$ & $0.0313(15)$ & $0.0480(16)$ & $-0.0143(13)$ & $0.0027(13)$ & $0.0013(12)$ \\
\hline $\mathrm{C} 243$ & $0.0381(13)$ & $0.0378(14)$ & $0.0362(12)$ & -0.0109 & $-0.0026(10)$ & $-0.0061(10)$ \\
\hline
\end{tabular}

Geometric parameters $\left(\AA,{ }^{\circ}\right)$

\begin{tabular}{|c|c|c|c|}
\hline $\mathrm{O} 15-\mathrm{C} 15$ & $1.213(3)$ & C132-H132 & 0.9500 \\
\hline $\mathrm{O} 25-\mathrm{C} 25$ & $1.214(3)$ & $\mathrm{C} 133-\mathrm{C} 134$ & $1.389(3)$ \\
\hline $\mathrm{O} 128-\mathrm{N} 127$ & $1.219(3)$ & C133-H133 & 0.9500 \\
\hline O129-N127 & $1.229(3)$ & $\mathrm{C} 134-\mathrm{C} 135$ & $1.373(4)$ \\
\hline O138-N137 & $1.224(3)$ & C134-N137 & $1.472(3)$ \\
\hline O139-N137 & $1.228(3)$ & $\mathrm{C} 135-\mathrm{C} 136$ & $1.386(4)$ \\
\hline $\mathrm{O} 228-\mathrm{N} 227$ & $1.212(3)$ & C135-H135 & 0.9500 \\
\hline $\mathrm{O} 229-\mathrm{N} 227$ & $1.220(3)$ & C136-H136 & 0.9500 \\
\hline $\mathrm{O} 238-\mathrm{N} 237$ & $1.229(3)$ & $\mathrm{C} 141-\mathrm{C} 143$ & $1.523(4)$ \\
\hline $\mathrm{O} 239-\mathrm{N} 237$ & $1.229(3)$ & $\mathrm{C} 141-\mathrm{C} 142$ & $1.524(4)$ \\
\hline $\mathrm{N} 11-\mathrm{C} 15$ & $1.388(3)$ & C141-H141 & 1.0000 \\
\hline
\end{tabular}




\begin{tabular}{|c|c|c|c|}
\hline N11-N111 & $1.388(3)$ & $\mathrm{C} 142-\mathrm{H} 14 \mathrm{D}$ & 0.9800 \\
\hline $\mathrm{N} 11-\mathrm{C} 12$ & $1.477(3)$ & $\mathrm{C} 142-\mathrm{H} 14 \mathrm{E}$ & 0.9800 \\
\hline $\mathrm{N} 13-\mathrm{C} 12$ & $1.456(3)$ & $\mathrm{C} 142-\mathrm{H} 14 \mathrm{~F}$ & 0.9800 \\
\hline $\mathrm{N} 13-\mathrm{C} 14$ & $1.479(3)$ & C143-H14A & 0.9800 \\
\hline N13-H13 & $0.89(3)$ & $\mathrm{C} 143-\mathrm{H} 14 \mathrm{~B}$ & 0.9800 \\
\hline $\mathrm{N} 21-\mathrm{C} 25$ & $1.375(3)$ & $\mathrm{C} 143-\mathrm{H} 14 \mathrm{C}$ & 0.9800 \\
\hline $\mathrm{N} 21-\mathrm{N} 211$ & $1.384(3)$ & $\mathrm{C} 212-\mathrm{C} 231$ & $1.469(3)$ \\
\hline $\mathrm{N} 21-\mathrm{C} 22$ & $1.470(3)$ & $\mathrm{C} 212-\mathrm{H} 212$ & 0.9500 \\
\hline $\mathrm{N} 23-\mathrm{C} 22$ & $1.471(3)$ & $\mathrm{C} 221-\mathrm{C} 226$ & $1.391(3)$ \\
\hline $\mathrm{N} 23-\mathrm{C} 24$ & $1.477(3)$ & $\mathrm{C} 221-\mathrm{C} 222$ & $1.396(3)$ \\
\hline $\mathrm{N} 23-\mathrm{H} 23$ & $0.89(4)$ & $\mathrm{C} 222-\mathrm{C} 223$ & $1.385(3)$ \\
\hline $\mathrm{N} 111-\mathrm{C} 112$ & $1.282(3)$ & $\mathrm{C} 222-\mathrm{H} 222$ & 0.9500 \\
\hline $\mathrm{N} 211-\mathrm{C} 212$ & $1.286(3)$ & $\mathrm{C} 223-\mathrm{C} 224$ & $1.384(3)$ \\
\hline $\mathrm{C} 12-\mathrm{C} 121$ & $1.507(3)$ & $\mathrm{C} 223-\mathrm{H} 223$ & 0.9500 \\
\hline $\mathrm{C} 12-\mathrm{H} 12$ & 1.0000 & $\mathrm{C} 224-\mathrm{C} 225$ & $1.385(3)$ \\
\hline $\mathrm{C} 14-\mathrm{C} 15$ & $1.516(3)$ & $\mathrm{C} 224-\mathrm{N} 227$ & $1.473(3)$ \\
\hline $\mathrm{C} 14-\mathrm{C} 141$ & $1.518(3)$ & $\mathrm{C} 225-\mathrm{C} 226$ & $1.387(3)$ \\
\hline $\mathrm{C} 14-\mathrm{H} 14$ & 1.0000 & $\mathrm{C} 225-\mathrm{H} 225$ & 0.9500 \\
\hline $\mathrm{C} 22-\mathrm{C} 221$ & $1.510(3)$ & $\mathrm{C} 226-\mathrm{H} 226$ & 0.9500 \\
\hline $\mathrm{C} 22-\mathrm{H} 22$ & 1.0000 & $\mathrm{C} 231-\mathrm{C} 232$ & $1.396(4)$ \\
\hline $\mathrm{C} 24-\mathrm{C} 25$ & $1.515(3)$ & $\mathrm{C} 231-\mathrm{C} 236$ & $1.401(3)$ \\
\hline $\mathrm{C} 24-\mathrm{C} 241$ & $1.533(3)$ & $\mathrm{C} 232-\mathrm{C} 233$ & $1.382(4)$ \\
\hline $\mathrm{C} 24-\mathrm{H} 24$ & 1.0000 & $\mathrm{C} 232-\mathrm{H} 232$ & 0.9500 \\
\hline $\mathrm{C} 112-\mathrm{C} 131$ & $1.465(3)$ & $\mathrm{C} 233-\mathrm{C} 234$ & $1.392(3)$ \\
\hline $\mathrm{C} 112-\mathrm{H} 112$ & 0.9500 & $\mathrm{C} 233-\mathrm{H} 233$ & 0.9500 \\
\hline $\mathrm{C} 121-\mathrm{C} 126$ & $1.389(3)$ & $\mathrm{C} 234-\mathrm{C} 235$ & $1.385(4)$ \\
\hline $\mathrm{C} 121-\mathrm{C} 122$ & $1.397(3)$ & $\mathrm{C} 234-\mathrm{N} 237$ & $1.467(3)$ \\
\hline $\mathrm{C} 122-\mathrm{C} 123$ & $1.381(3)$ & $\mathrm{C} 235-\mathrm{C} 236$ & $1.382(4)$ \\
\hline $\mathrm{C} 122-\mathrm{H} 122$ & 0.9500 & $\mathrm{C} 235-\mathrm{H} 235$ & 0.9500 \\
\hline $\mathrm{C} 123-\mathrm{C} 124$ & $1.379(4)$ & $\mathrm{C} 236-\mathrm{H} 236$ & 0.9500 \\
\hline C123-H123 & 0.9500 & $\mathrm{C} 241-\mathrm{C} 242$ & $1.521(4)$ \\
\hline $\mathrm{C} 124-\mathrm{C} 125$ & $1.379(3)$ & $\mathrm{C} 241-\mathrm{C} 243$ & $1.524(4)$ \\
\hline $\mathrm{C} 124-\mathrm{N} 127$ & $1.471(3)$ & $\mathrm{C} 241-\mathrm{H} 241$ & 1.0000 \\
\hline $\mathrm{C} 125-\mathrm{C} 126$ & $1.389(3)$ & $\mathrm{C} 242-\mathrm{H} 24 \mathrm{~A}$ & 0.9800 \\
\hline C125-H125 & 0.9500 & $\mathrm{C} 242-\mathrm{H} 24 \mathrm{~B}$ & 0.9800 \\
\hline $\mathrm{C} 126-\mathrm{H} 126$ & 0.9500 & $\mathrm{C} 242-\mathrm{H} 24 \mathrm{C}$ & 0.9800 \\
\hline $\mathrm{C} 131-\mathrm{C} 132$ & $1.395(3)$ & $\mathrm{C} 243-\mathrm{H} 24 \mathrm{D}$ & 0.9800 \\
\hline $\mathrm{C} 131-\mathrm{C} 136$ & $1.402(3)$ & $\mathrm{C} 243-\mathrm{H} 24 \mathrm{E}$ & 0.9800 \\
\hline $\mathrm{C} 132-\mathrm{C} 133$ & $1.377(3)$ & $\mathrm{C} 243-\mathrm{H} 24 \mathrm{~F}$ & 0.9800 \\
\hline $\mathrm{C} 15-\mathrm{N} 11-\mathrm{N} 111$ & $123.74(18)$ & $\mathrm{C} 131-\mathrm{C} 136-\mathrm{H} 136$ & 119.9 \\
\hline $\mathrm{C} 15-\mathrm{N} 11-\mathrm{C} 12$ & $109.37(18)$ & $\mathrm{O} 138-\mathrm{N} 137-\mathrm{O} 139$ & $123.9(2)$ \\
\hline $\mathrm{N} 111-\mathrm{N} 11-\mathrm{C} 12$ & $115.87(18)$ & $\mathrm{O} 138-\mathrm{N} 137-\mathrm{C} 134$ & $118.2(2)$ \\
\hline $\mathrm{C} 12-\mathrm{N} 13-\mathrm{C} 14$ & $104.96(18)$ & $\mathrm{O} 139-\mathrm{N} 137-\mathrm{C} 134$ & $117.8(2)$ \\
\hline $\mathrm{C} 12-\mathrm{N} 13-\mathrm{H} 13$ & $105.6(19)$ & $\mathrm{C} 14-\mathrm{C} 141-\mathrm{C} 143$ & $112.28(19)$ \\
\hline C14-N13-H13 & 109.4 (19) & $\mathrm{C} 14-\mathrm{C} 141-\mathrm{C} 142$ & $111.7(2)$ \\
\hline $\mathrm{C} 25-\mathrm{N} 21-\mathrm{N} 211$ & $129.5(2)$ & $\mathrm{C} 143-\mathrm{C} 141-\mathrm{C} 142$ & $112.2(2)$ \\
\hline $\mathrm{C} 25-\mathrm{N} 21-\mathrm{C} 22$ & $112.2(2)$ & $\mathrm{C} 14-\mathrm{C} 141-\mathrm{H} 141$ & 106.7 \\
\hline
\end{tabular}




\begin{tabular}{|c|c|c|c|}
\hline $\mathrm{N} 211-\mathrm{N} 21-\mathrm{C} 22$ & $116.06(19)$ & $\mathrm{C} 143-\mathrm{C} 141-\mathrm{H} 141$ & 106.7 \\
\hline $\mathrm{C} 22-\mathrm{N} 23-\mathrm{C} 24$ & $109.21(19)$ & $\mathrm{C} 142-\mathrm{C} 141-\mathrm{H} 141$ & 106.7 \\
\hline $\mathrm{C} 22-\mathrm{N} 23-\mathrm{H} 23$ & $111(2)$ & $\mathrm{C} 141-\mathrm{C} 142-\mathrm{H} 14 \mathrm{D}$ & 109.5 \\
\hline $\mathrm{C} 24-\mathrm{N} 23-\mathrm{H} 23$ & $112(2)$ & $\mathrm{C} 141-\mathrm{C} 142-\mathrm{H} 14 \mathrm{E}$ & 109.5 \\
\hline $\mathrm{C} 112-\mathrm{N} 111-\mathrm{N} 11$ & $117.58(19)$ & $\mathrm{H} 14 \mathrm{D}-\mathrm{C} 142-\mathrm{H} 14 \mathrm{E}$ & 109.5 \\
\hline $\mathrm{C} 212-\mathrm{N} 211-\mathrm{N} 21$ & $118.4(2)$ & $\mathrm{C} 141-\mathrm{C} 142-\mathrm{H} 14 \mathrm{~F}$ & 109.5 \\
\hline $\mathrm{N} 13-\mathrm{C} 12-\mathrm{N} 11$ & $104.41(18)$ & $\mathrm{H} 14 \mathrm{D}-\mathrm{C} 142-\mathrm{H} 14 \mathrm{~F}$ & 109.5 \\
\hline $\mathrm{N} 13-\mathrm{C} 12-\mathrm{C} 121$ & $112.35(19)$ & $\mathrm{H} 14 \mathrm{E}-\mathrm{C} 142-\mathrm{H} 14 \mathrm{~F}$ & 109.5 \\
\hline $\mathrm{N} 11-\mathrm{C} 12-\mathrm{C} 121$ & $114.42(19)$ & $\mathrm{C} 141-\mathrm{C} 143-\mathrm{H} 14 \mathrm{~A}$ & 109.5 \\
\hline N13-C12-H12 & 108.5 & $\mathrm{C} 141-\mathrm{C} 143-\mathrm{H} 14 \mathrm{~B}$ & 109.5 \\
\hline $\mathrm{N} 11-\mathrm{C} 12-\mathrm{H} 12$ & 108.5 & $\mathrm{H} 14 \mathrm{~A}-\mathrm{C} 143-\mathrm{H} 14 \mathrm{~B}$ & 109.5 \\
\hline $\mathrm{C} 121-\mathrm{C} 12-\mathrm{H} 12$ & 108.5 & $\mathrm{C} 141-\mathrm{C} 143-\mathrm{H} 14 \mathrm{C}$ & 109.5 \\
\hline $\mathrm{N} 13-\mathrm{C} 14-\mathrm{C} 15$ & $105.22(17)$ & $\mathrm{H} 14 \mathrm{~A}-\mathrm{C} 143-\mathrm{H} 14 \mathrm{C}$ & 109.5 \\
\hline $\mathrm{N} 13-\mathrm{C} 14-\mathrm{C} 141$ & $115.33(19)$ & $\mathrm{H} 14 \mathrm{~B}-\mathrm{C} 143-\mathrm{H} 14 \mathrm{C}$ & 109.5 \\
\hline $\mathrm{C} 15-\mathrm{C} 14-\mathrm{C} 141$ & $113.03(19)$ & $\mathrm{N} 211-\mathrm{C} 212-\mathrm{C} 231$ & $119.8(2)$ \\
\hline $\mathrm{N} 13-\mathrm{C} 14-\mathrm{H} 14$ & 107.6 & $\mathrm{~N} 211-\mathrm{C} 212-\mathrm{H} 212$ & 120.1 \\
\hline $\mathrm{C} 15-\mathrm{C} 14-\mathrm{H} 14$ & 107.6 & $\mathrm{C} 231-\mathrm{C} 212-\mathrm{H} 212$ & 120.1 \\
\hline $\mathrm{C} 141-\mathrm{C} 14-\mathrm{H} 14$ & 107.6 & $\mathrm{C} 226-\mathrm{C} 221-\mathrm{C} 222$ & $119.4(2)$ \\
\hline $\mathrm{O} 15-\mathrm{C} 15-\mathrm{N} 11$ & $125.9(2)$ & $\mathrm{C} 226-\mathrm{C} 221-\mathrm{C} 22$ & $122.8(2)$ \\
\hline $\mathrm{O} 15-\mathrm{C} 15-\mathrm{C} 14$ & $127.3(2)$ & $\mathrm{C} 222-\mathrm{C} 221-\mathrm{C} 22$ & $117.8(2)$ \\
\hline $\mathrm{N} 11-\mathrm{C} 15-\mathrm{C} 14$ & $106.73(18)$ & $\mathrm{C} 223-\mathrm{C} 222-\mathrm{C} 221$ & $121.0(2)$ \\
\hline $\mathrm{N} 21-\mathrm{C} 22-\mathrm{N} 23$ & $104.4(2)$ & $\mathrm{C} 223-\mathrm{C} 222-\mathrm{H} 222$ & 119.5 \\
\hline $\mathrm{N} 21-\mathrm{C} 22-\mathrm{C} 221$ & $114.65(19)$ & $\mathrm{C} 221-\mathrm{C} 222-\mathrm{H} 222$ & 119.5 \\
\hline $\mathrm{N} 23-\mathrm{C} 22-\mathrm{C} 221$ & $110.4(2)$ & $\mathrm{C} 224-\mathrm{C} 223-\mathrm{C} 222$ & $118.1(2)$ \\
\hline $\mathrm{N} 21-\mathrm{C} 22-\mathrm{H} 22$ & 109.1 & $\mathrm{C} 224-\mathrm{C} 223-\mathrm{H} 223$ & 120.9 \\
\hline $\mathrm{N} 23-\mathrm{C} 22-\mathrm{H} 22$ & 109.1 & $\mathrm{C} 222-\mathrm{C} 223-\mathrm{H} 223$ & 120.9 \\
\hline $\mathrm{C} 221-\mathrm{C} 22-\mathrm{H} 22$ & 109.1 & $\mathrm{C} 223-\mathrm{C} 224-\mathrm{C} 225$ & $122.4(2)$ \\
\hline $\mathrm{N} 23-\mathrm{C} 24-\mathrm{C} 25$ & $104.9(2)$ & $\mathrm{C} 223-\mathrm{C} 224-\mathrm{N} 227$ & $118.9(2)$ \\
\hline $\mathrm{N} 23-\mathrm{C} 24-\mathrm{C} 241$ & $113.3(2)$ & $\mathrm{C} 225-\mathrm{C} 224-\mathrm{N} 227$ & $118.7(2)$ \\
\hline $\mathrm{C} 25-\mathrm{C} 24-\mathrm{C} 241$ & $111.6(2)$ & $\mathrm{C} 224-\mathrm{C} 225-\mathrm{C} 226$ & $118.6(2)$ \\
\hline $\mathrm{N} 23-\mathrm{C} 24-\mathrm{H} 24$ & 108.9 & $\mathrm{C} 224-\mathrm{C} 225-\mathrm{H} 225$ & 120.7 \\
\hline $\mathrm{C} 25-\mathrm{C} 24-\mathrm{H} 24$ & 108.9 & $\mathrm{C} 226-\mathrm{C} 225-\mathrm{H} 225$ & 120.7 \\
\hline $\mathrm{C} 241-\mathrm{C} 24-\mathrm{H} 24$ & 108.9 & $\mathrm{C} 225-\mathrm{C} 226-\mathrm{C} 221$ & $120.5(2)$ \\
\hline $\mathrm{O} 25-\mathrm{C} 25-\mathrm{N} 21$ & $126.1(2)$ & $\mathrm{C} 225-\mathrm{C} 226-\mathrm{H} 226$ & 119.8 \\
\hline $\mathrm{O} 25-\mathrm{C} 25-\mathrm{C} 24$ & $125.9(2)$ & $\mathrm{C} 221-\mathrm{C} 226-\mathrm{H} 226$ & 119.8 \\
\hline $\mathrm{N} 21-\mathrm{C} 25-\mathrm{C} 24$ & $108.0(2)$ & $\mathrm{O} 228-\mathrm{N} 227-\mathrm{O} 229$ & $123.0(2)$ \\
\hline $\mathrm{N} 111-\mathrm{C} 112-\mathrm{C} 131$ & $119.0(2)$ & $\mathrm{O} 228-\mathrm{N} 227-\mathrm{C} 224$ & $118.5(2)$ \\
\hline $\mathrm{N} 111-\mathrm{C} 112-\mathrm{H} 112$ & 120.5 & $\mathrm{O} 229-\mathrm{N} 227-\mathrm{C} 224$ & $118.5(2)$ \\
\hline $\mathrm{C} 131-\mathrm{C} 112-\mathrm{H} 112$ & 120.5 & $\mathrm{C} 232-\mathrm{C} 231-\mathrm{C} 236$ & $119.5(2)$ \\
\hline $\mathrm{C} 126-\mathrm{C} 121-\mathrm{C} 122$ & $119.4(2)$ & $\mathrm{C} 232-\mathrm{C} 231-\mathrm{C} 212$ & $122.6(2)$ \\
\hline $\mathrm{C} 126-\mathrm{C} 121-\mathrm{C} 12$ & $123.4(2)$ & $\mathrm{C} 236-\mathrm{C} 231-\mathrm{C} 212$ & $117.9(2)$ \\
\hline $\mathrm{C} 122-\mathrm{C} 121-\mathrm{C} 12$ & $117.2(2)$ & $\mathrm{C} 233-\mathrm{C} 232-\mathrm{C} 231$ & $120.6(2)$ \\
\hline $\mathrm{C} 123-\mathrm{C} 122-\mathrm{C} 121$ & $121.2(2)$ & $\mathrm{C} 233-\mathrm{C} 232-\mathrm{H} 232$ & 119.7 \\
\hline $\mathrm{C} 123-\mathrm{C} 122-\mathrm{H} 122$ & 119.4 & $\mathrm{C} 231-\mathrm{C} 232-\mathrm{H} 232$ & 119.7 \\
\hline $\mathrm{C} 121-\mathrm{C} 122-\mathrm{H} 122$ & 119.4 & $\mathrm{C} 232-\mathrm{C} 233-\mathrm{C} 234$ & $118.4(2)$ \\
\hline $\mathrm{C} 124-\mathrm{C} 123-\mathrm{C} 122$ & $117.7(2)$ & $\mathrm{C} 232-\mathrm{C} 233-\mathrm{H} 233$ & 120.8 \\
\hline $\mathrm{C} 124-\mathrm{C} 123-\mathrm{H} 123$ & 121.1 & $\mathrm{C} 234-\mathrm{C} 233-\mathrm{H} 233$ & 120.8 \\
\hline $\mathrm{C} 122-\mathrm{C} 123-\mathrm{H} 123$ & 121.1 & $\mathrm{C} 235-\mathrm{C} 234-\mathrm{C} 233$ & $122.5(2)$ \\
\hline
\end{tabular}




\begin{tabular}{|c|c|c|c|}
\hline $\mathrm{C} 125-\mathrm{C} 124-\mathrm{C} 123$ & $122.8(2)$ & $\mathrm{C} 235-\mathrm{C} 234-\mathrm{N} 237$ & $118.5(2)$ \\
\hline $\mathrm{C} 125-\mathrm{C} 124-\mathrm{N} 127$ & $118.7(2)$ & $\mathrm{C} 233-\mathrm{C} 234-\mathrm{N} 237$ & $119.0(2)$ \\
\hline $\mathrm{C} 123-\mathrm{C} 124-\mathrm{N} 127$ & $118.4(2)$ & $\mathrm{C} 236-\mathrm{C} 235-\mathrm{C} 234$ & $118.4(2)$ \\
\hline $\mathrm{C} 124-\mathrm{C} 125-\mathrm{C} 126$ & $118.7(2)$ & $\mathrm{C} 236-\mathrm{C} 235-\mathrm{H} 235$ & 120.8 \\
\hline $\mathrm{C} 124-\mathrm{C} 125-\mathrm{H} 125$ & 120.7 & $\mathrm{C} 234-\mathrm{C} 235-\mathrm{H} 235$ & 120.8 \\
\hline $\mathrm{C} 126-\mathrm{C} 125-\mathrm{H} 125$ & 120.7 & $\mathrm{C} 235-\mathrm{C} 236-\mathrm{C} 231$ & $120.6(2)$ \\
\hline $\mathrm{C} 121-\mathrm{C} 126-\mathrm{C} 125$ & $120.1(2)$ & $\mathrm{C} 235-\mathrm{C} 236-\mathrm{H} 236$ & 119.7 \\
\hline $\mathrm{C} 121-\mathrm{C} 126-\mathrm{H} 126$ & 120.0 & $\mathrm{C} 231-\mathrm{C} 236-\mathrm{H} 236$ & 119.7 \\
\hline $\mathrm{C} 125-\mathrm{C} 126-\mathrm{H} 126$ & 120.0 & $\mathrm{O} 239-\mathrm{N} 237-\mathrm{O} 238$ & $123.4(2)$ \\
\hline $\mathrm{O} 128-\mathrm{N} 127-\mathrm{O} 129$ & $122.8(2)$ & $\mathrm{O} 239-\mathrm{N} 237-\mathrm{C} 234$ & $118.0(2)$ \\
\hline $\mathrm{O} 128-\mathrm{N} 127-\mathrm{C} 124$ & $118.8(2)$ & $\mathrm{O} 238-\mathrm{N} 237-\mathrm{C} 234$ & $118.6(2)$ \\
\hline $\mathrm{O} 129-\mathrm{N} 127-\mathrm{C} 124$ & $118.3(2)$ & $\mathrm{C} 242-\mathrm{C} 241-\mathrm{C} 243$ & $111.2(2)$ \\
\hline $\mathrm{C} 132-\mathrm{C} 131-\mathrm{C} 136$ & $119.3(2)$ & $\mathrm{C} 242-\mathrm{C} 241-\mathrm{C} 24$ & $110.5(2)$ \\
\hline $\mathrm{C} 132-\mathrm{C} 131-\mathrm{C} 112$ & $121.6(2)$ & $\mathrm{C} 243-\mathrm{C} 241-\mathrm{C} 24$ & $111.3(2)$ \\
\hline $\mathrm{C} 136-\mathrm{C} 131-\mathrm{C} 112$ & $119.1(2)$ & $\mathrm{C} 242-\mathrm{C} 241-\mathrm{H} 241$ & 107.9 \\
\hline $\mathrm{C} 133-\mathrm{C} 132-\mathrm{C} 131$ & $121.1(2)$ & $\mathrm{C} 243-\mathrm{C} 241-\mathrm{H} 241$ & 107.9 \\
\hline $\mathrm{C} 133-\mathrm{C} 132-\mathrm{H} 132$ & 119.5 & $\mathrm{C} 24-\mathrm{C} 241-\mathrm{H} 241$ & 107.9 \\
\hline $\mathrm{C} 131-\mathrm{C} 132-\mathrm{H} 132$ & 119.5 & $\mathrm{C} 241-\mathrm{C} 242-\mathrm{H} 24 \mathrm{~A}$ & 109.5 \\
\hline $\mathrm{C} 132-\mathrm{C} 133-\mathrm{C} 134$ & $118.0(2)$ & $\mathrm{C} 241-\mathrm{C} 242-\mathrm{H} 24 \mathrm{~B}$ & 109.5 \\
\hline $\mathrm{C} 132-\mathrm{C} 133-\mathrm{H} 133$ & 121.0 & $\mathrm{H} 24 \mathrm{~A}-\mathrm{C} 242-\mathrm{H} 24 \mathrm{~B}$ & 109.5 \\
\hline $\mathrm{C} 134-\mathrm{C} 133-\mathrm{H} 133$ & 121.0 & $\mathrm{C} 241-\mathrm{C} 242-\mathrm{H} 24 \mathrm{C}$ & 109.5 \\
\hline $\mathrm{C} 135-\mathrm{C} 134-\mathrm{C} 133$ & $122.9(2)$ & $\mathrm{H} 24 \mathrm{~A}-\mathrm{C} 242-\mathrm{H} 24 \mathrm{C}$ & 109.5 \\
\hline $\mathrm{C} 135-\mathrm{C} 134-\mathrm{N} 137$ & $119.2(2)$ & $\mathrm{H} 24 \mathrm{~B}-\mathrm{C} 242-\mathrm{H} 24 \mathrm{C}$ & 109.5 \\
\hline $\mathrm{C} 133-\mathrm{C} 134-\mathrm{N} 137$ & $118.0(2)$ & $\mathrm{C} 241-\mathrm{C} 243-\mathrm{H} 24 \mathrm{D}$ & 109.5 \\
\hline $\mathrm{C} 134-\mathrm{C} 135-\mathrm{C} 136$ & $118.7(2)$ & $\mathrm{C} 241-\mathrm{C} 243-\mathrm{H} 24 \mathrm{E}$ & 109.5 \\
\hline $\mathrm{C} 134-\mathrm{C} 135-\mathrm{H} 135$ & 120.7 & $\mathrm{H} 24 \mathrm{D}-\mathrm{C} 243-\mathrm{H} 24 \mathrm{E}$ & 109.5 \\
\hline $\mathrm{C} 136-\mathrm{C} 135-\mathrm{H} 135$ & 120.7 & $\mathrm{C} 241-\mathrm{C} 243-\mathrm{H} 24 \mathrm{~F}$ & 109.5 \\
\hline $\mathrm{C} 135-\mathrm{C} 136-\mathrm{C} 131$ & $120.1(2)$ & $\mathrm{H} 24 \mathrm{D}-\mathrm{C} 243-\mathrm{H} 24 \mathrm{~F}$ & 109.5 \\
\hline $\mathrm{C} 135-\mathrm{C} 136-\mathrm{H} 136$ & 119.9 & $\mathrm{H} 24 \mathrm{E}-\mathrm{C} 243-\mathrm{H} 24 \mathrm{~F}$ & 109.5 \\
\hline $\mathrm{C} 15-\mathrm{N} 11-\mathrm{N} 111-\mathrm{C} 112$ & $43.7(3)$ & $\mathrm{C} 136-\mathrm{C} 131-\mathrm{C} 132-\mathrm{C} 133$ & $-0.8(3)$ \\
\hline $\mathrm{C} 12-\mathrm{N} 11-\mathrm{N} 111-\mathrm{C} 112$ & $-176.19(19)$ & $\mathrm{C} 112-\mathrm{C} 131-\mathrm{C} 132-\mathrm{C} 133$ & $178.75(19)$ \\
\hline $\mathrm{C} 25-\mathrm{N} 21-\mathrm{N} 211-\mathrm{C} 212$ & $-18.6(3)$ & $\mathrm{C} 131-\mathrm{C} 132-\mathrm{C} 133-\mathrm{C} 134$ & $0.0(3)$ \\
\hline $\mathrm{C} 22-\mathrm{N} 21-\mathrm{N} 211-\mathrm{C} 212$ & $179.98(19)$ & $\mathrm{C} 132-\mathrm{C} 133-\mathrm{C} 134-\mathrm{C} 135$ & $0.6(3)$ \\
\hline $\mathrm{C} 14-\mathrm{N} 13-\mathrm{C} 12-\mathrm{N} 11$ & $30.7(2)$ & $\mathrm{C} 132-\mathrm{C} 133-\mathrm{C} 134-\mathrm{N} 137$ & $179.92(18)$ \\
\hline $\mathrm{C} 14-\mathrm{N} 13-\mathrm{C} 12-\mathrm{C} 121$ & $155.3(2)$ & $\mathrm{C} 133-\mathrm{C} 134-\mathrm{C} 135-\mathrm{C} 136$ & $-0.5(3)$ \\
\hline $\mathrm{C} 15-\mathrm{N} 11-\mathrm{C} 12-\mathrm{N} 13$ & $-25.8(2)$ & $\mathrm{N} 137-\mathrm{C} 134-\mathrm{C} 135-\mathrm{C} 136$ & $-179.8(2)$ \\
\hline $\mathrm{N} 111-\mathrm{N} 11-\mathrm{C} 12-\mathrm{N} 13$ & $-171.33(18)$ & $\mathrm{C} 134-\mathrm{C} 135-\mathrm{C} 136-\mathrm{C} 131$ & $-0.3(3)$ \\
\hline $\mathrm{C} 15-\mathrm{N} 11-\mathrm{C} 12-\mathrm{C} 121$ & $-149.0(2)$ & $\mathrm{C} 132-\mathrm{C} 131-\mathrm{C} 136-\mathrm{C} 135$ & $0.9(3)$ \\
\hline $\mathrm{N} 111-\mathrm{N} 11-\mathrm{C} 12-\mathrm{C} 121$ & $65.4(3)$ & $\mathrm{C} 112-\mathrm{C} 131-\mathrm{C} 136-\mathrm{C} 135$ & $-178.6(2)$ \\
\hline $\mathrm{C} 12-\mathrm{N} 13-\mathrm{C} 14-\mathrm{C} 15$ & $-25.1(2)$ & $\mathrm{C} 135-\mathrm{C} 134-\mathrm{N} 137-\mathrm{O} 138$ & $172.8(2)$ \\
\hline $\mathrm{C} 12-\mathrm{N} 13-\mathrm{C} 14-\mathrm{C} 141$ & $-150.3(2)$ & $\mathrm{C} 133-\mathrm{C} 134-\mathrm{N} 137-\mathrm{O} 138$ & $-6.5(3)$ \\
\hline $\mathrm{N} 111-\mathrm{N} 11-\mathrm{C} 15-\mathrm{O} 15$ & $-26.3(4)$ & $\mathrm{C} 135-\mathrm{C} 134-\mathrm{N} 137-\mathrm{O} 139$ & $-7.6(3)$ \\
\hline $\mathrm{C} 12-\mathrm{N} 11-\mathrm{C} 15-\mathrm{O} 15$ & $-168.6(2)$ & $\mathrm{C} 133-\mathrm{C} 134-\mathrm{N} 137-\mathrm{O} 139$ & $173.1(2)$ \\
\hline $\mathrm{N} 111-\mathrm{N} 11-\mathrm{C} 15-\mathrm{C} 14$ & $152.1(2)$ & $\mathrm{N} 13-\mathrm{C} 14-\mathrm{C} 141-\mathrm{C} 143$ & $59.6(3)$ \\
\hline $\mathrm{C} 12-\mathrm{N} 11-\mathrm{C} 15-\mathrm{C} 14$ & $9.9(3)$ & $\mathrm{C} 15-\mathrm{C} 14-\mathrm{C} 141-\mathrm{C} 143$ & $-61.5(3)$ \\
\hline $\mathrm{N} 13-\mathrm{C} 14-\mathrm{C} 15-\mathrm{O} 15$ & $-172.1(2)$ & $\mathrm{N} 13-\mathrm{C} 14-\mathrm{C} 141-\mathrm{C} 142$ & $-67.5(3)$ \\
\hline $\mathrm{C} 141-\mathrm{C} 14-\mathrm{C} 15-\mathrm{O} 15$ & $-45.4(3)$ & $\mathrm{C} 15-\mathrm{C} 14-\mathrm{C} 141-\mathrm{C} 142$ & $171.4(2)$ \\
\hline
\end{tabular}




\begin{tabular}{|c|c|}
\hline $\mathrm{N} 13-\mathrm{C} 14-\mathrm{C} 15-\mathrm{N} 11$ & $9.5(2)$ \\
\hline $\mathrm{C} 141-\mathrm{C} 14-\mathrm{C} 15-\mathrm{N} 11$ & $136.1(2)$ \\
\hline $\mathrm{C} 25-\mathrm{N} 21-\mathrm{C} 22-\mathrm{N} 23$ & $9.8(3)$ \\
\hline $\mathrm{N} 211-\mathrm{N} 21-\mathrm{C} 22-\mathrm{N} 23$ & $174.33(17)$ \\
\hline $\mathrm{C} 25-\mathrm{N} 21-\mathrm{C} 22-\mathrm{C} 221$ & $130.7(2)$ \\
\hline $\mathrm{N} 211-\mathrm{N} 21-\mathrm{C} 22-\mathrm{C} 221$ & $-64.7(3)$ \\
\hline $\mathrm{C} 24-\mathrm{N} 23-\mathrm{C} 22-\mathrm{N} 21$ & $-11.1(3)$ \\
\hline $\mathrm{C} 24-\mathrm{N} 23-\mathrm{C} 22-\mathrm{C} 221$ & $-134.8(2)$ \\
\hline $\mathrm{C} 22-\mathrm{N} 23-\mathrm{C} 24-\mathrm{C} 25$ & $8.6(3)$ \\
\hline $\mathrm{C} 22-\mathrm{N} 23-\mathrm{C} 24-\mathrm{C} 241$ & $-113.4(2)$ \\
\hline $\mathrm{N} 211-\mathrm{N} 21-\mathrm{C} 25-\mathrm{O} 25$ & $12.8(4)$ \\
\hline $\mathrm{C} 22-\mathrm{N} 21-\mathrm{C} 25-\mathrm{O} 25$ & $174.8(2)$ \\
\hline $\mathrm{N} 211-\mathrm{N} 21-\mathrm{C} 25-\mathrm{C} 24$ & $-166.5(2)$ \\
\hline $\mathrm{C} 22-\mathrm{N} 21-\mathrm{C} 25-\mathrm{C} 24$ & $-4.6(3)$ \\
\hline $\mathrm{N} 23-\mathrm{C} 24-\mathrm{C} 25-\mathrm{O} 25$ & $178.1(2)$ \\
\hline $\mathrm{C} 241-\mathrm{C} 24-\mathrm{C} 25-\mathrm{O} 25$ & $-58.8(3)$ \\
\hline $\mathrm{N} 23-\mathrm{C} 24-\mathrm{C} 25-\mathrm{N} 21$ & $-2.5(3)$ \\
\hline $\mathrm{C} 241-\mathrm{C} 24-\mathrm{C} 25-\mathrm{N} 21$ & $120.6(2)$ \\
\hline $\mathrm{N} 11-\mathrm{N} 111-\mathrm{C} 112-\mathrm{C} 131$ & $-177.45(18$ \\
\hline $\mathrm{N} 13-\mathrm{C} 12-\mathrm{C} 121-\mathrm{C} 126$ & $-109.4(3)$ \\
\hline $\mathrm{N} 11-\mathrm{C} 12-\mathrm{C} 121-\mathrm{C} 126$ & $9.5(3)$ \\
\hline $\mathrm{N} 13-\mathrm{C} 12-\mathrm{C} 121-\mathrm{C} 122$ & $71.3(3)$ \\
\hline $\mathrm{N} 11-\mathrm{C} 12-\mathrm{C} 121-\mathrm{C} 122$ & $-169.9(2)$ \\
\hline $\mathrm{C} 126-\mathrm{C} 121-\mathrm{C} 122-\mathrm{C} 123$ & $-1.5(4)$ \\
\hline $\mathrm{C} 12-\mathrm{C} 121-\mathrm{C} 122-\mathrm{C} 123$ & $177.8(2)$ \\
\hline $\mathrm{C} 121-\mathrm{C} 122-\mathrm{C} 123-\mathrm{C} 124$ & $-0.8(4)$ \\
\hline $\mathrm{C} 122-\mathrm{C} 123-\mathrm{C} 124-\mathrm{C} 125$ & $2.0(4)$ \\
\hline $\mathrm{C} 122-\mathrm{C} 123-\mathrm{C} 124-\mathrm{N} 127$ & $-177.5(2)$ \\
\hline $\mathrm{C} 123-\mathrm{C} 124-\mathrm{C} 125-\mathrm{C} 126$ & $-0.8(4)$ \\
\hline $\mathrm{N} 127-\mathrm{C} 124-\mathrm{C} 125-\mathrm{C} 126$ & $178.8(2)$ \\
\hline $\mathrm{C} 122-\mathrm{C} 121-\mathrm{C} 126-\mathrm{C} 125$ & $2.8(4)$ \\
\hline $\mathrm{C} 12-\mathrm{C} 121-\mathrm{C} 126-\mathrm{C} 125$ & $-176.5(2)$ \\
\hline $\mathrm{C} 124-\mathrm{C} 125-\mathrm{C} 126-\mathrm{C} 121$ & $-1.7(4)$ \\
\hline $\mathrm{C} 125-\mathrm{C} 124-\mathrm{N} 127-\mathrm{O} 128$ & $177.3(2)$ \\
\hline $\mathrm{C} 123-\mathrm{C} 124-\mathrm{N} 127-\mathrm{O} 128$ & $-3.1(4)$ \\
\hline $\mathrm{C} 125-\mathrm{C} 124-\mathrm{N} 127-\mathrm{O} 129$ & $-1.2(4)$ \\
\hline $\mathrm{C} 123-\mathrm{C} 124-\mathrm{N} 127-\mathrm{O} 129$ & $178.4(2)$ \\
\hline $\mathrm{N} 111-\mathrm{C} 112-\mathrm{C} 131-\mathrm{C} 132$ & $-7.8(3)$ \\
\hline $\mathrm{N} 111-\mathrm{C} 112-\mathrm{C} 131-\mathrm{C} 136$ & $171.7(2)$ \\
\hline
\end{tabular}

\begin{tabular}{|c|c|}
\hline $\mathrm{N} 21-\mathrm{N} 211-\mathrm{C} 212-\mathrm{C} 231$ & $-179.07(18)$ \\
\hline $\mathrm{N} 21-\mathrm{C} 22-\mathrm{C} 221-\mathrm{C} 226$ & $-9.1(3)$ \\
\hline $\mathrm{N} 23-\mathrm{C} 22-\mathrm{C} 221-\mathrm{C} 226$ & $108.5(3)$ \\
\hline $\mathrm{N} 21-\mathrm{C} 22-\mathrm{C} 221-\mathrm{C} 222$ & $173.6(2)$ \\
\hline $\mathrm{N} 23-\mathrm{C} 22-\mathrm{C} 221-\mathrm{C} 222$ & $-68.8(3)$ \\
\hline $\mathrm{C} 226-\mathrm{C} 221-\mathrm{C} 222-\mathrm{C} 223$ & $-2.2(4)$ \\
\hline $\mathrm{C} 22-\mathrm{C} 221-\mathrm{C} 222-\mathrm{C} 223$ & $175.3(2)$ \\
\hline $\mathrm{C} 221-\mathrm{C} 222-\mathrm{C} 223-\mathrm{C} 224$ & $1.5(4)$ \\
\hline $\mathrm{C} 222-\mathrm{C} 223-\mathrm{C} 224-\mathrm{C} 225$ & $0.4(4)$ \\
\hline $\mathrm{C} 222-\mathrm{C} 223-\mathrm{C} 224-\mathrm{N} 227$ & $-178.5(2)$ \\
\hline $\mathrm{C} 223-\mathrm{C} 224-\mathrm{C} 225-\mathrm{C} 226$ & $-1.7(4)$ \\
\hline $\mathrm{N} 227-\mathrm{C} 224-\mathrm{C} 225-\mathrm{C} 226$ & $177.2(2)$ \\
\hline $\mathrm{C} 224-\mathrm{C} 225-\mathrm{C} 226-\mathrm{C} 221$ & $1.1(4)$ \\
\hline $\mathrm{C} 222-\mathrm{C} 221-\mathrm{C} 226-\mathrm{C} 225$ & $0.8(4)$ \\
\hline $\mathrm{C} 22-\mathrm{C} 221-\mathrm{C} 226-\mathrm{C} 225$ & $-176.5(2)$ \\
\hline $\mathrm{C} 223-\mathrm{C} 224-\mathrm{N} 227-\mathrm{O} 228$ & $1.5(3)$ \\
\hline $\mathrm{C} 225-\mathrm{C} 224-\mathrm{N} 227-\mathrm{O} 228$ & $-177.5(2)$ \\
\hline $\mathrm{C} 223-\mathrm{C} 224-\mathrm{N} 227-\mathrm{O} 229$ & $178.7(2)$ \\
\hline $\mathrm{C} 225-\mathrm{C} 224-\mathrm{N} 227-\mathrm{O} 229$ & $-0.3(3)$ \\
\hline $\mathrm{N} 211-\mathrm{C} 212-\mathrm{C} 231-\mathrm{C} 232$ & $9.0(3)$ \\
\hline $\mathrm{N} 211-\mathrm{C} 212-\mathrm{C} 231-\mathrm{C} 236$ & $-172.1(2)$ \\
\hline $\mathrm{C} 236-\mathrm{C} 231-\mathrm{C} 232-\mathrm{C} 233$ & $0.4(3)$ \\
\hline $\mathrm{C} 212-\mathrm{C} 231-\mathrm{C} 232-\mathrm{C} 233$ & $179.3(2)$ \\
\hline $\mathrm{C} 231-\mathrm{C} 232-\mathrm{C} 233-\mathrm{C} 234$ & $-0.4(3)$ \\
\hline $\mathrm{C} 232-\mathrm{C} 233-\mathrm{C} 234-\mathrm{C} 235$ & $0.1(3)$ \\
\hline $\mathrm{C} 232-\mathrm{C} 233-\mathrm{C} 234-\mathrm{N} 237$ & $-179.35(19)$ \\
\hline $\mathrm{C} 233-\mathrm{C} 234-\mathrm{C} 235-\mathrm{C} 236$ & $0.2(3)$ \\
\hline $\mathrm{N} 237-\mathrm{C} 234-\mathrm{C} 235-\mathrm{C} 236$ & $179.65(19)$ \\
\hline $\mathrm{C} 234-\mathrm{C} 235-\mathrm{C} 236-\mathrm{C} 231$ & $-0.2(3)$ \\
\hline $\mathrm{C} 232-\mathrm{C} 231-\mathrm{C} 236-\mathrm{C} 235$ & $-0.1(3)$ \\
\hline $\mathrm{C} 212-\mathrm{C} 231-\mathrm{C} 236-\mathrm{C} 235$ & $-179.0(2)$ \\
\hline $\mathrm{C} 235-\mathrm{C} 234-\mathrm{N} 237-\mathrm{O} 239$ & $5.9(3)$ \\
\hline $\mathrm{C} 233-\mathrm{C} 234-\mathrm{N} 237-\mathrm{O} 239$ & $-174.7(2)$ \\
\hline $\mathrm{C} 235-\mathrm{C} 234-\mathrm{N} 237-\mathrm{O} 238$ & $-174.1(2)$ \\
\hline $\mathrm{C} 233-\mathrm{C} 234-\mathrm{N} 237-\mathrm{O} 238$ & $5.3(3)$ \\
\hline $\mathrm{N} 23-\mathrm{C} 24-\mathrm{C} 241-\mathrm{C} 242$ & $-77.5(3)$ \\
\hline $\mathrm{C} 25-\mathrm{C} 24-\mathrm{C} 241-\mathrm{C} 242$ & $164.3(2)$ \\
\hline $\mathrm{N} 23-\mathrm{C} 24-\mathrm{C} 241-\mathrm{C} 243$ & $46.6(3)$ \\
\hline $\mathrm{C} 25-\mathrm{C} 24-\mathrm{C} 241-\mathrm{C} 243$ & $-71.7(3)$ \\
\hline
\end{tabular}

Hydrogen-bond geometry $\left(\AA,{ }^{\circ}\right)$

\begin{tabular}{lllll}
\hline$D-\mathrm{H} \cdots A$ & $D-\mathrm{H}$ & $\mathrm{H} \cdots A$ & $D \cdots A$ & $D-\mathrm{H} \cdots A$ \\
\hline $\mathrm{N} 23-\mathrm{H} 23 \cdots \mathrm{O} 128^{\mathrm{i}}$ & $0.89(4)$ & $2.55(4)$ & $3.338(3)$ & $147(3)$ \\
$\mathrm{N} 23-\mathrm{H} 23 \cdots \mathrm{O} 129^{\mathrm{i}}$ & $0.89(4)$ & $2.36(4)$ & $3.202(3)$ & $159(3)$ \\
$\mathrm{C} 112-\mathrm{H} 112 \cdots \mathrm{O} 15$ & 0.95 & 2.30 & $2.822(3)$ & 114 \\
$\mathrm{C} 212-\mathrm{H} 212 \cdots \mathrm{O} 25$ & 0.95 & 2.16 & $2.832(3)$ & 127 \\
$\mathrm{C} 133-\mathrm{H} 133 \cdots \mathrm{O} 15^{\mathrm{ii}}$ & 0.95 & 2.29 & $3.154(3)$ & 151
\end{tabular}




$\begin{array}{llllr}\mathrm{C} 233-\mathrm{H} 233 \cdots \mathrm{O} 25^{\mathrm{iii}} & 0.95 & 2.36 & 3.141(3) & 139 \\ \mathrm{C} 243-\mathrm{H} 24 D \cdots \mathrm{O} 138 & 0.98 & 2.52 & 3.480(3) & 165 \\ \mathrm{C} 122-\mathrm{H} 122 \cdots \mathrm{O} 129^{\text {iv }} & 0.95 & 2.48 & 3.212(3) & 134 \\ \mathrm{C} 222-\mathrm{H} 222 \cdots \mathrm{O} 229^{\mathrm{v}} & 0.95 & 2.60 & 3.297(3) & 131 \\ \mathrm{C} 226-\mathrm{H} 226 \cdots \mathrm{O} 139^{\text {iv }} & 0.95 & 2.57 & 3.197(3) & 124\end{array}$

Symmetry codes: (i) $x+1, y-1, z+1$; (ii) $x, y-1, z$; (iii) $x, y+1, z$; (iv) $x+1, y, z$; (v) $x-1, y, z$. 